\title{
Influence of Sediment Cycling on the Rare-Earth Element Geochemistry of Fluvial Deposits (Caculuvar-Mucope, Cunene River Basin, Angola)
}

\author{
Armanda Cruz ${ }^{1}$, Pedro A. Dinis ${ }^{1, * \mathbb{C}}$, Alberto Gomes ${ }^{2} \mathbb{D}$ and Paula Leite ${ }^{2}$ \\ 1 MARE-Marine and Environmental Sciences Centre, Departament of Earth Sciences, University of Coimbra, \\ 3030-790 Coimbra, Portugal; armandatrindade@hotmail.com \\ 2 CEGOT-Centre of Studies in Geography and Spatial Planning, Department of Geography, \\ University of Porto, 4150-564 Porto, Portugal; atgomes@letras.up.pt (A.G.); paulacpintoleite@gmail.com (P.L.) \\ * Correspondence: pdinis@dct.uc.pt
}

check for

updates

Citation: Cruz, A.; Dinis, P.A.; Gomes, A.; Leite, P. Influence of Sediment Cycling on the Rare-Earth Element Geochemistry of Fluvial Deposits (Caculuvar-Mucope, Cunene River Basin, Angola). Geosciences 2021, 11, 384. https:// doi.org/10.3390/geosciences11090384

Academic Editors: Philippe Claeys and Jesus Martinez-Frias

Received: 18 July 2021

Accepted: 8 September 2021

Published: 11 September 2021

Publisher's Note: MDPI stays neutral with regard to jurisdictional claims in published maps and institutional affiliations.

Copyright: (c) 2021 by the authors. Licensee MDPI, Basel, Switzerland. This article is an open access article distributed under the terms and conditions of the Creative Commons Attribution (CC BY) license (https:/ / creativecommons.org/licenses/by/ $4.0 /)$.

\begin{abstract}
The rare-earth element (REE) geochemistry of sedimentary deposits has been used in provenance investigations despite the transformation that this group of elements may suffer during a depositional cycle. In the present investigation, we used the geochemistry and XRD mineralogy of a set of sand and mud fluvial deposits to evaluate the ability of REE parameters in provenance tracing, and the changes in REE geochemistry associated with weathering and sorting. The analyzed deposits were generated in a subtropical drainage basin where mafic and felsic units are evenly represented, and these crystalline rocks are covered by sedimentary successions in a wide portion of the basin. A few element ratios appear to hold robust information about primary sources (Eu/Y, $\mathrm{Eu} / \mathrm{Eu}^{*}, \mathrm{La}_{\mathrm{N}} / \mathrm{Yb}_{\mathrm{N}}, \mathrm{La}_{\mathrm{N}} / \mathrm{Sm}_{\mathrm{N}}$, and $\left.\mathrm{Gd}_{\mathrm{N}} / \mathrm{Yb}_{\mathrm{N}}\right)$, and the provenance signal is best preserved in sand than in mud deposits. Sediment cycles, however, change the REE geochemistry, affecting mud and sand deposits differently. They are responsible for significant REE depletion through quartz dilution in sands and may promote discernible changes in REE patterns in muds (e.g., increase in Ce content and some light REE depletion relative to heavy REE).
\end{abstract}

Keywords: rare-earth elements; fluvial sediments; recognition of primary sources; exogenous compositional transformations; Cunene River Basin

\section{Introduction}

Rare-earth elements (REE) have received major attention due to their economic importance for new technologies, with special emphasis on green energies, electronics, informatics, and innovative agricultural practices. An increasing demand for REE has thus been observed worldwide during recent decades [1,2]. REE deposits can be formed through magmatic, metamorphic or hydrothermal primary processes or be associated with secondary processes involving weathering and erosion of primary sources $[1,3]$. As REE tend to be insoluble in surface environments, their concentrations in a sedimentary deposit reflect the respective source area geology. Hence, the REE patterns of river sediments, besides being used to identify commercially valuable deposits, are frequently applied in provenance investigations without a direct economic focus [4-9]. However, the REE patterns of river sediments can be affected by exogenous processes, such as weathering [10-14] and sorting [5,11-17]. For example, fine-grained deposits are expected to be particularly influenced by weathering-related transformations $[18,19]$, but REE geochemistry is still widely used to trace the provenance of mud deposits $[6,7,20,21]$. The cumulative effects of exogenous changes associated with multiple depositional cycles are likely to have a major influence on REE geochemistry where the recycled component is abundant.

The present investigation is focused on the geochemistry of a set of present-day sand and mud deposits from the Caculuvar River basin, a sub-basin of the Cunene River in 
the subtropical SW of Angola (Figure 1). It aims to better understand (1) the source rock control on the REE contents of the produced sediment and (2) the exogenous processes that influence the REE geochemistry. In the study region, two trunk rivers are separated by a ridgeline striking broadly north-south, leaving the Caculuvar sub-basin to the west and the Mucope sub-basin river to the east (Figure 2). The Caculuvar trunk river flows through an upstream sector, where felsic igneous rocks largely prevail, and a downstream sector, mainly with mafic igneous rocks, before entering the Kalahari Basin; the Mucope is entirely placed in the Kalahari Basin, thus draining exclusively a recent sedimentary succession. Several geological features of the investigated area, such as the similar representation of mafic and felsic crystalline rocks, and the good separation of regions with sharply different geologies, provide unique conditions to assess how the recycling of sediments with different primary sources controls REE geochemistry.

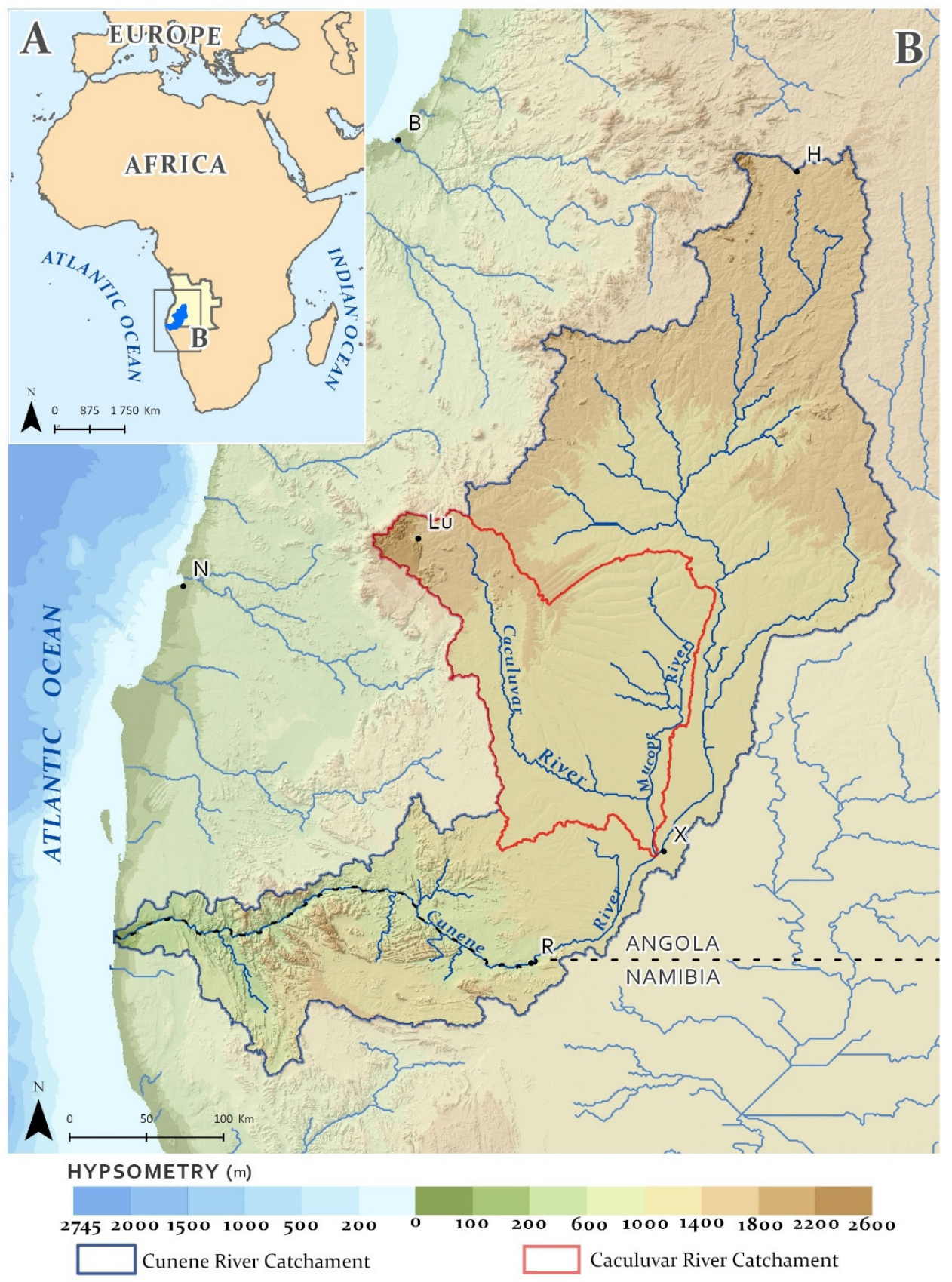

Figure 1. Location of the Cunene (A) and Caculuvar (B) basins in the SW of Africa. 


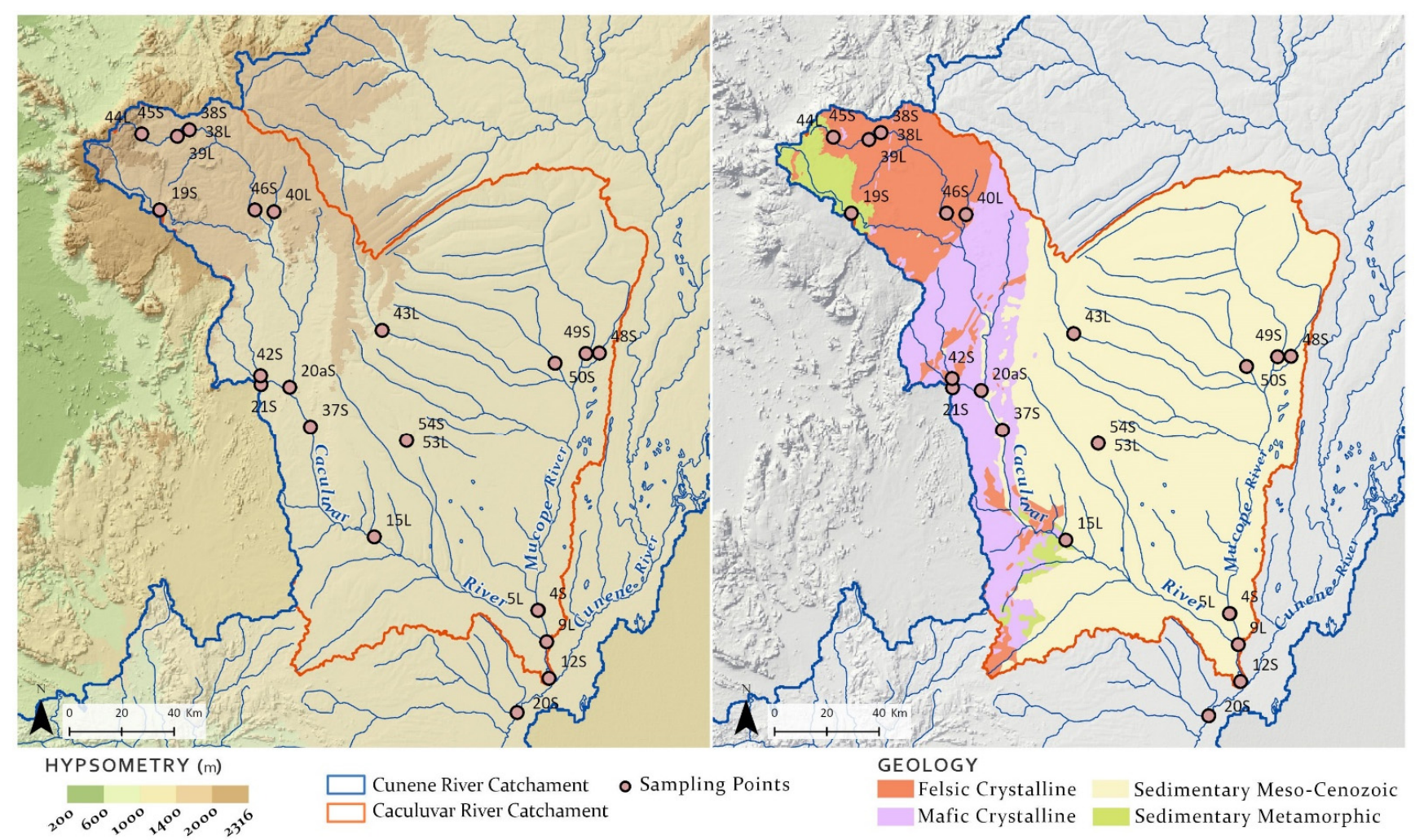

Figure 2. Sampling sites and the orography (left panel) and geology (right panel) of their source areas. Geology is based on the Geological Map of Angola, scale 1/1,000,000, sheet 3 [22].

\section{Regional Setting}

\subsection{Geology}

The Caculuvar River, with a length of $273 \mathrm{~km}$ and a drainage basin of $25,322 \mathrm{~km}^{2}$, is the biggest tributary of the Cunene River. The Caculuvar River basin integrates two trunk rivers, the Caculuvar and the Mucope. The catchment areas of these trunk rivers (hereafter referred to as the Caculuvar and Mucope sub-basins) are approximately the same size. The two rivers only join together less than $10 \mathrm{~km}$ from the confluence with the Cunene. The geologies of the Caculuvar and Mucope sub-basins are substantially different. The Mucope River is entirely placed in the sedimentary units of the Kalahari Basin, while the Caculuvar mostly drains the Angolan Block of the Congo Craton, entering the Kalahari only in its downstream path (Figure 2).

Different units of the Angolan Block are drained by the Caculuvar River. In the NW tip of the catchment belonging to the Humpata-Bimbe Plateau, its headwaters drain the Proterozoic Chela Group and Leba Formation [23]. The Chela Group comprises a succession of siliciclastic rocks of different grain sizes and intercalated volcanoclastic rocks that, as a general rule, are Si-rich. Zircon grains retrieved from rhyolitic beds allow dating the Chela Group at the Paleoproterozoic [24]. Occasionally, younger igneous rocks ( $1.5 \mathrm{Ga})$ enriched in the mafic component also occur [25]. The Leba Formation unconformably overlies the Chela Group in the higher elevation areas of the Humpata-Bimbe Plateau. It consists mostly of dark dolomitic limestones, frequently with well-preserved stromatolites.

Southward, the Caculuvar flows on the pre-Chela basement, which is dominated by intrusive rocks. In northern locations, the so-called "regional granite" occurs [26]. In general, it is a deformed peraluminous leucocratic granite associated with the Eburnean orogeny $(\sim 2.0 \mathrm{Ga})[24,27]$. Further downstream, the river drains Mesoproterozoic mafic rocks of the Kunene Complex of SW Angola, previously called the gabbro-anorthosite complex [27-29]. These units, coupled with their continuation in Namibia, constitute the 
largest mafic complex of Africa. In places, between outliers of the Kunene Complex of SW Angola, coeval A-type red granites that usually strike SW-NE occur [30].

After crossing the eastern border of the Kunene Complex of SW Angola, the Caculuvar River enters the Kalahari Basin approximately $85 \mathrm{~km}$ upstream of its confluence with the Mucope. Its sedimentary infill includes the Kalahari Group with aeolian and fluvial deposits dated at the late Cretaceous to Cainozoic [31] and a series of Quaternary loose sands associated with the recycling of the Kalahari Group.

\subsection{Climate}

The climate of the Caculuvar catchment presents substantial seasonal variation, with a wet season, from October to April, in which heavy rainfall and high temperatures occur, and a dry season, from May to September, with lower temperatures [32]. At these latitudes, the influence that some processes such as the El Niño Southern Oscillation (ENSO) and the Angola Low (AL) play on rainfall significantly varies. At the interannual scale, ENSO is primarily responsible for rainfall variations in southern Africa [33], giving rise to seasonal below-normal rainfall [34]. In contrast, the AL is a low-pressure system occurring from October to March, favoring the wet periods, bringing the summer rains [35].

According to the Koppen-Geiger climate classification (http:/ / koeppen-geiger.vuwien.ac.at/present.htm, accessed on 26 March 2021), in the Caculuvar catchment, the mountainous sector of the basin to the NW has a subtropical highland climate $(\mathrm{Cwb})$, transitioning as we move southwards to a hot semi-arid climate (Bsh). In this way, despite registering a tropical thermal regime softened by the catchment's mountainous distribution (monthly average close to $22^{\circ} \mathrm{C}$ ), the average temperature increases to the east and south In contrast, the annual precipitation varies in the opposite direction. The southern sectors of the Caculuvar and Mucope catchments record about $450-500 \mathrm{~mm}$ per year, while in the north, particularly in the mountainous sector of the basin, about $900-950 \mathrm{~mm}$ per year is recorded (Figure 2).

\section{Methods}

For this study, the main lithological data came from the Geological Map of Angola, at a scale of $1 / 1,000,000$, sheet 3 , published in 1980 [22]. The delimitation of the basins, sub-basins, and hydrographic network was carried out in GIS and based on the altimetric data from SRTM DEM V4, with a $30 \mathrm{~m}$ pixel size. The selection of the sampling sites was carried out according to geomorphological and geological criteria, considering two main objectives: (1) the choice of sampling points along the main river, individualized by major lithological sectors to capture the sediments of the sector, and those coming from the upstream sub-catchments; and (2) the choice of sampling points in exclusive subcatchments of each of the major lithological sectors to obtain only sediments of that sector. Following these criteria, field locations were first defined on the cabinet by observing imagery from the Google Earth and Terra Incognita platforms (to evaluate the terrestrial access and sediment availability) and then transferred to a database to use in the field. In total, 25 present-day sediment samples were selected for compositional analyses, including 15 sands and 10 muds (Table 1; Figure 2).

The mineralogical composition was determined, for both sand and mud deposits, by $\mathrm{X}$-ray diffraction (XRD) using an Aeris instrument (PanAlytical) with a $\mathrm{Cu}$ tube, at $15 \mathrm{kV}, 40 \mathrm{~mA}$. Diffractograms were obtained on the ground (to $<15 \mu \mathrm{m}$ ) with randomly oriented grains in the range $2-60^{\circ} 2 \theta$. Semi-quantitative estimations of mineral proportions were based on the areas of characteristic reflections identified in the diffractograms after extracting the background. Estimations were performed for quartz (peaks at $3.34 \AA$, after correcting for mica reflection, and $4.26 \AA$ ), K-feldspar (peak at $\sim 3.24 \AA$ ), plagioclase $(\sim 3.18 \AA)$, calcite $(\sim 3.03 \AA)$, pyroxene $(\sim 2.9$ and $2.95 \AA)$, hematite $(\sim 2.7 \AA)$, and phyllosilicates (summed reflections of $\sim 7 \AA, 10 \AA, 12-13 \AA$, and $14-15 \AA$ ). 
Table 1. Representation of different geological units in the catchment areas of the sampling points and overall XRD mineralogy obtained for each sediment sample (\% values).

\begin{tabular}{ccccccccccc}
\hline Sample & Source Type & Felsic & Mafic & Sedim. & Meta-Sed & Quartz & KF & Plagioc & Phyllos & Others \\
\hline Sands & & & & & & & & & & \\
\hline 38S & Felsic & 78.4 & 1.6 & & 20.0 & 40 & 42 & 9 & 6 & 2 \\
39S & Felsic & 64.8 & 0.8 & & 34.4 & 89 & 0 & 6 & 4 & 1 \\
45S & Felsic & 77.5 & & & 22.5 & 91 & 0 & 0 & 7 & 2 \\
46S & Felsic & 89.5 & 1.1 & & 9.4 & 63 & 17 & 6 & 8 & 6 \\
21S & Mafic & 13.2 & 86.8 & & & 47 & 23 & 21 & 0 & 10 \\
42S & Mafic & 32.7 & 66.5 & 0.2 & 0.7 & 34 & 16 & 47 & 1 & 3 \\
20S & Cunene & 14 & 4 & 63 & 18 & 84 & 0 & 5 & 0 & 11 \\
12S & Mixed & 13.1 & 15.0 & 68.3 & 3.7 & 77 & 15 & 2 & 3 & 3 \\
20aS & Mixed & 47.5 & 31.9 & 7.7 & 12.9 & 56 & 31 & 7 & 4 & 2 \\
37S & Mixed & 41.7 & 40.3 & 7.8 & 10.2 & 14 & 26 & 51 & 7 & 2 \\
4S & Recycled & & & 100 & & 100 & 0 & 0 & 0 & 0 \\
19S & Recycled & 4.5 & & 99.5 & & 96 & 0 & 0 & 3 & 2 \\
48S & Recycled & & & 100.0 & & 93 & 0 & 4 & 3 & 0 \\
49S & Recycled & & & 100.0 & & 96 & 3 & 0 & 0 & 1 \\
50S & Recycled & & & 100.0 & & 92 & 0 & 0 & 5 & 3 \\
54S & Recycled & & & 100.0 & & 97 & 0 & 0 & 2 & 1 \\
\hline Muds & & & & & & & & & & \\
\hline 38L & Felsic & 78.4 & 1.6 & & 20.0 & 19 & 18 & 15 & 45 & 4 \\
39L & Felsic & 64.8 & 0.8 & & 34.4 & 34 & 24 & 5 & 29 & 7 \\
44L & Felsic & 77.5 & & & 22.5 & 31 & 39 & 5 & 23 & 1 \\
15L & Mixed & 36.0 & 41.2 & 13.9 & 8.9 & 38 & 0 & 36 & 26 & 0 \\
40L & Mixed & 30.1 & 39.9 & & & & 35 & 24 & 5 & 29 \\
5L & Recycled & & & 100.0 & & 43 & 0 & 0 & 57 & 0 \\
9L & Recycled & & & 100.0 & & 33 & 19 & 13 & 33 & 2 \\
43L & Recycled & & & 100.0 & & 35 & 14 & 0 & 38 & 14 \\
53L & Recycled & & & 100.0 & & 73 & 2 & 0 & 24 & 0 \\
\hline
\end{tabular}

Sedim.: sedimentary; Meta-sed.: meta-sedimentary; KF: K-feldspars; Plagioc.: plagioclases; Phyllos: phyllosilicates.

Chemical element concentrations were determined with the same aliquots $(\sim 5 \mathrm{gr})$ used for bulk mineralogy. Analyses were performed at the laboratories of Bureau Veritas (Vancouver; group 4A-4B and code LF200) (Supplementary Material Table S1). Most major oxides were determined by ICP-AES (using a Spectro Ciros/Arcos instrument) and trace elements by ICP-MS (using an ICPMS ELAN 9000 instrument), following a lithium metaborate/tetraborate fusion and nitric acid digestion. For quality control, accuracy was obtained through the standard STD SO-19. The estimated errors for the elements considered in this research were, in general, below $2 \%$ and, except for $\operatorname{Sm}(\sim 6 \%)$, always below $5 \%$. Blanks were almost always below the detection level.

The composition of the Upper Continental Crust (UCC; [36,37]) was applied for the normalization of the geochemical data. Lanthanides were also normalized to the chondrite composition [38], with the fractionation parameters being computed after this normalization. For simplicity, REE are grouped here as light REE (LREE; $\mathrm{La}, \mathrm{Ce}, \mathrm{Pr}, \mathrm{Nd}$, and $\mathrm{Sm}$ ), Eu, and heavy REE (HREE; Gd, Tb, Dy, Ho, Er, Tm, Yb, and Lu). In the analysis and graphical representations, $\mathrm{Y}$ and Sc were separated from the REE. Univariate and multivariate statistical analyses were performed using the software JMP Pro 14.0. To better evaluate the associations between compositional parameters, principal component analysis (PCA) was performed on different sets of geochemical results. 


\section{Results}

\subsection{Sediment Classification Based on Source Geology}

Sampled sediments can be classified into four types according to the geology of their catchment areas (Table 1). Where the drainage area includes mafic and felsic crystalline rocks and each represents at least $\sim 1 / 3$ of the crystalline component (i.e., after excluding sedimentary and low-grade meta-sedimentary terranes), the source is classified as mixed. Felsic and mafic sources are considered where one of these rock types is prevalent, and the (meta-)sedimentary cover does not occupy more than $75 \%$ of the drainage area. Otherwise, the sampling sites are considered to have a recycled source. With one exception, collected in the upstream portion of the Caculuvar sub-basin, recycled sediments came from the Mucope sub-basin. Mafic-derived sediments were collected within the Kunene Complex of SW Angola, while felsic-derived sediments came from upstream locations in streams draining the Eburnean granitoids. Sampling sites in the Cunene and at the middle to lower courses of the Caculuvar are mixed source.

\subsection{Mineralogy}

The XRD mineralogy is presented in Table 1. Sand samples yield variable amounts of quartz and feldspar, with phyllosilicates in secondary to minor amounts. Carbonates and Fe oxides can be present in minor amounts. Sands with a sedimentary to meta-sedimentary source are strongly enriched in quartz $(>92 \%)$. Mafic-derived sediments tend to hold more feldspar and less quartz than felsic-derived sediments. The composition of sands with a mixed source are widely variable, revealing either a clear enrichment in quartz, especially where sedimentary units occupy extensive areas of the respective catchments (12S), or abundant feldspar, namely, near the downstream border of the Kunene Complex of SW Angola (37S).

Except for some sediments with a dominant recycled component, which contain very low feldspar, sampled muds usually yield similar proportions of quartz, phyllosilicates, and feldspar. Recycled muds (i.e., mainly sourced by previous sedimentary and metasedimentary units) can yield the highest contents of quartz (73\%) or phyllosilicates (57\%). The proportions of feldspar in felsic-derived and mixed-source muds are not substantially different $(24-44 \%)$. Carbonates were detected in some felsic and recycled muds, but always in secondary to minor amounts.

\subsection{Overall Geochemistry}

Sand composition is widely variable, particularly with regards to the concentrations of mobile elements $\mathrm{Na}, \mathrm{Ca}, \mathrm{K}, \mathrm{Mg}$, $\mathrm{Sr}, \mathrm{Rb}$, and $\mathrm{Ba}$ (Figure 3). Sands yield more $\mathrm{SiO}_{2}$ than muds. Conversely, the contents of $\mathrm{Fe}_{2} \mathrm{O}_{3}, \mathrm{MgO}$, $\mathrm{REE}$ (including $\mathrm{Y}$ and $\mathrm{Sc}$ ), $\mathrm{Cs}, \mathrm{U}, \mathrm{V}, \mathrm{Zr}$, and $\mathrm{Hf}$ tend to be higher in muds. Lost on ignition is minor in sands (0.9-4.4\%) and moderately high in muds (11.9-18.5\%).

All sand deposits are dominated by $\mathrm{SiO}_{2}(60.1-97.4 \%)$, containing $\mathrm{Al}_{2} \mathrm{O}_{3}(0.9-20.3 \%)$, $\mathrm{CaO}$ (non-detected to $9.3 \%$ ), $\mathrm{Fe}_{2} \mathrm{O}_{3}(0.2-4.3 \%), \mathrm{K}_{2} \mathrm{O}(0.02-4.56 \%), \mathrm{Na}_{2} \mathrm{O}$ (non-detected to $3.1 \%)$, and $\mathrm{TiO}_{2}(0.1-2.9 \%)$ in more variable percentages. The abundances of other elements are always below $1 \%$. As expected, sands mainly derived from mafic-dominated source areas are enriched in $\mathrm{CaO}, \mathrm{Fe}_{2} \mathrm{O}_{3}, \mathrm{TiO}_{2}, \mathrm{MgO}$, and $\mathrm{Sr}$ (Figure 3; Table 2). They are also distinguished by enrichment in Eu relative to the other sand samples. Felsic-derived sands are distinguished by relatively high contents of $\mathrm{K}_{2} \mathrm{O}$ and $\mathrm{Rb}$. Sand derived from sedimentary units yields the lowest contents of mobile elements such as $\mathrm{Na}, \mathrm{Ca}$, and $\mathrm{K}$ and are the most enriched in silica ( $>93 \%$ ).

Muds are still dominated by $\mathrm{SiO}_{2}(47.1-65.9 \%)$ and, compared to sands, yield higher and more homogenous contents of $\mathrm{Al}_{2} \mathrm{O}_{3}(13.1-25.5 \%)$ and $\mathrm{Fe}_{2} \mathrm{O}_{3}(3.2-8.0 \%)$. Except for $\mathrm{Na}_{2} \mathrm{O}$, which occurs in lesser amounts in recycled sediments, the element abundances measured in muds with different source geologies broadly overlap (Figure 3). 


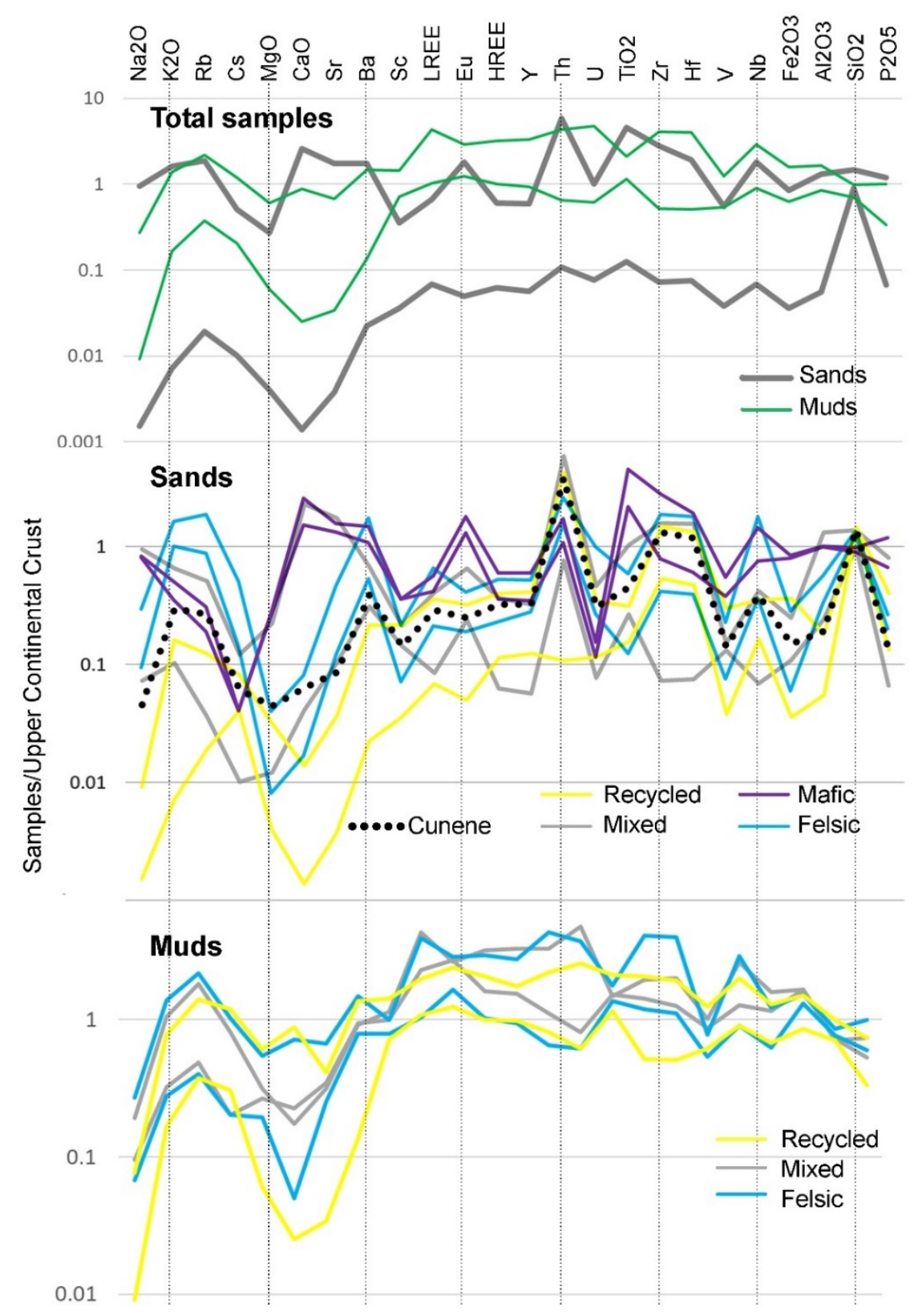

Figure 3. Overall geochemistry of sand and mud deposits, and the composition of sands and muds with distinct source geologies. The range of concentrations between maximum and minimum values is represented in the diagrams.

Table 2. Selection of geochemical data obtained with the studied sediments.

\begin{tabular}{|c|c|c|c|c|c|c|c|c|c|c|c|c|c|c|c|c|c|c|c|c|c|}
\hline & Source & $\mathrm{SiO}_{2}$ & $\mathrm{Al}_{2} \mathrm{O}_{3}$ & ${ }_{3} \mathrm{MgO}$ & $\mathrm{CaO}$ & $\mathrm{Na}_{2} \mathrm{O}$ & $\mathrm{K}_{2} \mathrm{O}$ & $\mathbf{L a}$ & $\mathrm{Ce}$ & Pr & $\mathrm{Nd}$ & $\mathrm{Sm}$ & Eu & Gd & $\mathrm{Tb}$ & Dy & Ho & $\mathrm{Er}$ & $\mathrm{Tm}$ & $\mathrm{Yb}$ & Lu \\
\hline \multicolumn{22}{|c|}{ Muds } \\
\hline $39 \mathrm{~L}$ & Fels & 52.5 & 23.57 & 0.56 & 0.39 & 0.44 & 3.39 & 120.5 & 257.9 & 28.07 & 101 & 16.06 & 2.88 & 13.27 & 1.9 & 10.48 & 2.19 & 5.94 & 0.94 & 6.31 & 0.97 \\
\hline $44 \mathrm{~L}$ & Fels & 57.3 & 21.79 & 0.48 & 0.18 & 0.22 & 3.87 & 92.1 & 183.1 & 18.63 & 64.5 & 10.47 & 1.87 & 8.82 & 1.27 & 7.32 & 1.58 & 4.83 & 0.77 & 5.35 & 0.91 \\
\hline P15 & Mix & 51.47 & 20.27 & 1.35 & 2.57 & 0.89 & 0.78 & 30.1 & 67.8 & 7.15 & 27 & 5.18 & 1.65 & 4.52 & 0.65 & 3.88 & 0.75 & 2.17 & 0.3 & 2.02 & 0.3 \\
\hline $38 \mathrm{~L}$ & Fels & 48.16 & 25.47 & 0.78 & 0.63 & 0.63 & 2.93 & 133 & 286.5 & 29.96 & 104.7 & 16.91 & 2.65 & 13.32 & 2.01 & 11.42 & 2.31 & 7.25 & 1.09 & 7.4 & 1.17 \\
\hline $40 \mathrm{~L}$ & Mix & 47.06 & 25.43 & 0.66 & 0.81 & 0.31 & 0.91 & 70.9 & 147.1 & 16.91 & 60.2 & 9.66 & 2.7 & 8.2 & 1.1 & 5.86 & 1.11 & 3.26 & 0.47 & 2.8 & 0.44 \\
\hline P5 & $\operatorname{Rec}$ & 65.92 & 13.14 & 0.89 & 0.63 & 0.11 & 1.46 & 35.4 & 85.1 & 8.54 & 30.1 & 5.88 & 1.24 & 4.98 & 0.76 & 4.36 & 0.89 & 2.68 & 0.41 & 2.7 & 0.42 \\
\hline $9 \mathrm{~L}$ & $\operatorname{Rec}$ & 47.41 & 23.06 & 1.24 & 1.38 & 0.25 & 0.61 & 33.4 & 67.2 & 7.94 & 28.9 & 5.56 & 1.57 & 4.71 & 0.64 & 3.73 & 0.74 & 2.1 & 0.29 & 1.9 & 0.27 \\
\hline $43 \mathrm{~L}$ & $\operatorname{Rec}$ & 50.48 & 18.48 & 1.5 & 3.18 & 0.12 & 2.18 & 55.1 & 101.6 & 13.95 & 51.1 & 9.46 & 2.21 & 8.33 & 1.22 & 6.8 & 1.35 & 3.86 & 0.53 & 3.25 & 0.53 \\
\hline P53L & $\operatorname{Rec}$ & 52.1 & 22.96 & 0.15 & 0.09 & 0.03 & 0.47 & 44 & 139.8 & 13.7 & 52.4 & 11.48 & 2.41 & 8.88 & 1.34 & 7.73 & 1.52 & 4.32 & 0.65 & 4.4 & 0.67 \\
\hline
\end{tabular}


Table 2. Cont.

\begin{tabular}{|c|c|c|c|c|c|c|c|c|c|c|c|c|c|c|c|c|c|c|c|c|c|}
\hline & Source & $\mathrm{SiO}_{2}$ & $\mathrm{Al}_{2} \mathrm{O}_{3}$ & $\mathrm{MgO}$ & $\mathrm{CaO}$ & $\mathrm{Na}_{2} \mathrm{O}$ & $\mathrm{K}_{2} \mathrm{O}$ & La & $\mathrm{Ce}$ & $\operatorname{Pr}$ & $\mathrm{Nd}$ & $\mathrm{Sm}$ & $\mathbf{E u}$ & $\mathrm{Gd}$ & $\mathrm{Tb}$ & Dy & Ho & Er & $\mathrm{Tm}$ & $\mathrm{Yb}$ & $\mathbf{L u}$ \\
\hline \multicolumn{22}{|c|}{ Sands } \\
\hline $20 S$ & Cun & 92.62 & 2.95 & 0.11 & 0.23 & 0.15 & 0.84 & 9.7 & 18.6 & 1.99 & 7.2 & 1.28 & 0.25 & 1.14 & 0.18 & 1.14 & 0.22 & 0.8 & 0.12 & 0.9 & 0.12 \\
\hline $12 S$ & Mix & 91.62 & 3.74 & 0.03 & 0.15 & 0.24 & 1.84 & 13.2 & 27.1 & 2.8 & 9.8 & 1.63 & 0.24 & 1.44 & 0.2 & 1.29 & 0.24 & 0.81 & 0.13 & 0.98 & 0.15 \\
\hline $20 \mathrm{aS}$ & Mix & 83.81 & 7.81 & 0.15 & 2.48 & 1.33 & 0.88 & 7.6 & 15.8 & 1.78 & 7.1 & 1.32 & 0.65 & 1.06 & 0.15 & 0.88 & 0.16 & 0.47 & 0.06 & 0.45 & 0.07 \\
\hline $37 \mathrm{~S}$ & Mix & 64.62 & 20.26 & 0.55 & 8.29 & 3.12 & 0.29 & 3.6 & 4.6 & 0.61 & 2.1 & 0.31 & 0.46 & 0.39 & 0.04 & 0.25 & 0.05 & 0.13 & 0.005 & 0.025 & 0.01 \\
\hline $38 \mathrm{~S}$ & Mix & 82.27 & 8.68 & 0.1 & 0.29 & 0.97 & 4.56 & 16.8 & 51.5 & 3.77 & 13.2 & 2.09 & 0.4 & 1.78 & 0.24 & 1.42 & 0.32 & 1 & 0.15 & 0.9 & 0.16 \\
\hline $39 S$ & Fels & 89.48 & 5.11 & 0.02 & 0.06 & 0.36 & 3.44 & 7.3 & 13.7 & 1.41 & 5 & 0.77 & 0.19 & 0.75 & 0.13 & 0.91 & 0.19 & 0.58 & 0.1 & 0.57 & 0.1 \\
\hline $45 S$ & Fels & 84.59 & 7.42 & 0.1 & 0.08 & 0.31 & 3.84 & 21.1 & 36.7 & 4.15 & 14.4 & 2.36 & 0.41 & 1.9 & 0.29 & 1.82 & 0.38 & 1.32 & 0.2 & 1.37 & 0.28 \\
\hline $46 S$ & Fels & 89.25 & 5.15 & 0.04 & 0.21 & 0.54 & 2.81 & 9.6 & 20.6 & 2.01 & 7.2 & 1.16 & 0.29 & 1.04 & 0.2 & 1.38 & 0.33 & 1.04 & 0.15 & 0.96 & 0.15 \\
\hline $21 S$ & Mafic & 60.06 & 15.48 & 0.68 & 9.25 & 2.73 & 1.42 & 19.5 & 32.3 & 4.2 & 16.3 & 3.06 & 1.81 & 2.79 & 0.41 & 2.27 & 0.45 & 1.29 & 0.18 & 1.06 & 0.18 \\
\hline $42 S$ & Mafic & 65.42 & 15.35 & 0.65 & 5.45 & 2.65 & 0.99 & 12.9 & 26.7 & 2.86 & 11.1 & 2 & 1.32 & 1.73 & 0.23 & 1.26 & 0.25 & 0.77 & 0.12 & 0.64 & 0.14 \\
\hline $4 S$ & $\operatorname{Rec}$ & 97.25 & 0.85 & 0.03 & 0.04 & 0.03 & 0.28 & 3.2 & 5.7 & 0.56 & 2.1 & 0.42 & 0.07 & 0.42 & 0.06 & 0.42 & 0.09 & 0.28 & 0.04 & 0.38 & 0.05 \\
\hline $19 S$ & Fels & 92.38 & 2.79 & 0.08 & 0.03 & 0.02 & 0.45 & 11.9 & 22.9 & 2.58 & 9.1 & 1.53 & 0.32 & 1.38 & 0.24 & 1.49 & 0.31 & 0.93 & 0.15 & 1.1 & 0.17 \\
\hline $48 \mathrm{~S}$ & $\operatorname{Rec}$ & 94.94 & 1.74 & 0.03 & 0.04 & 0.005 & 0.31 & 5.2 & 9.5 & 1.21 & 4.4 & 0.88 & 0.17 & 0.72 & 0.12 & 0.82 & 0.17 & 0.57 & 0.08 & 0.64 & 0.11 \\
\hline $49 S$ & $\operatorname{Rec}$ & 97.36 & 0.86 & 0.02 & 0.03 & 0.02 & 0.31 & 2.4 & 4.2 & 0.49 & 1.7 & 0.3 & 0.05 & 0.3 & 0.06 & 0.38 & 0.09 & 0.26 & 0.05 & 0.42 & 0.07 \\
\hline $50 S$ & $\operatorname{Rec}$ & 96.16 & 1.13 & 0.04 & 0.05 & 0.01 & 0.16 & 4.2 & 9 & 0.82 & 3.1 & 0.54 & 0.12 & 0.53 & 0.07 & 0.52 & 0.11 & 0.35 & 0.05 & 0.41 & 0.07 \\
\hline
\end{tabular}

Chemical contents as \% for major oxides and $\mathrm{mg} / \mathrm{kg}$ for REE. Mix: mixed; Fels: felsic; Rec: recycled.

\subsection{REE Grades and Patterns}

The concentrations of REE are substantially higher in muds $\left(153.5<\sum R E E<619.7\right.$; $\left.137.2<\sum L R E E<571.1 ; 14.4<\sum H R E E<45.0\right)$ than in sands $\left(10.8<\sum R E E<93.7 ; 9.1<\sum \mathrm{LREE}<91.0\right.$; $0.9<\sum$ HREE < 8.6). Muds are also enriched in $Y(19.7-69.4 \mathrm{mg} / \mathrm{kg})$ and Sc $(10-20 \mathrm{mg} / \mathrm{kg})$ relative to sands $(1.2-12.5 \mathrm{mg} / \mathrm{kg} ; 0.5-5 \mathrm{mg} / \mathrm{kg}$ ) (Figure 4). REE display a strong correlation with $\mathrm{Y}$ and a moderate correlation with Th both in sands and muds (Figure 5). No correlation is observed between REE and $\mathrm{Zr}$ in sands and between REE and Sc in muds. Fairly good correlations are observed between Eu and Y and Sc. The correlation Y-Eu becomes especially robust in sands after isolating sediments enriched in felsic and mafic components (Figure 5).

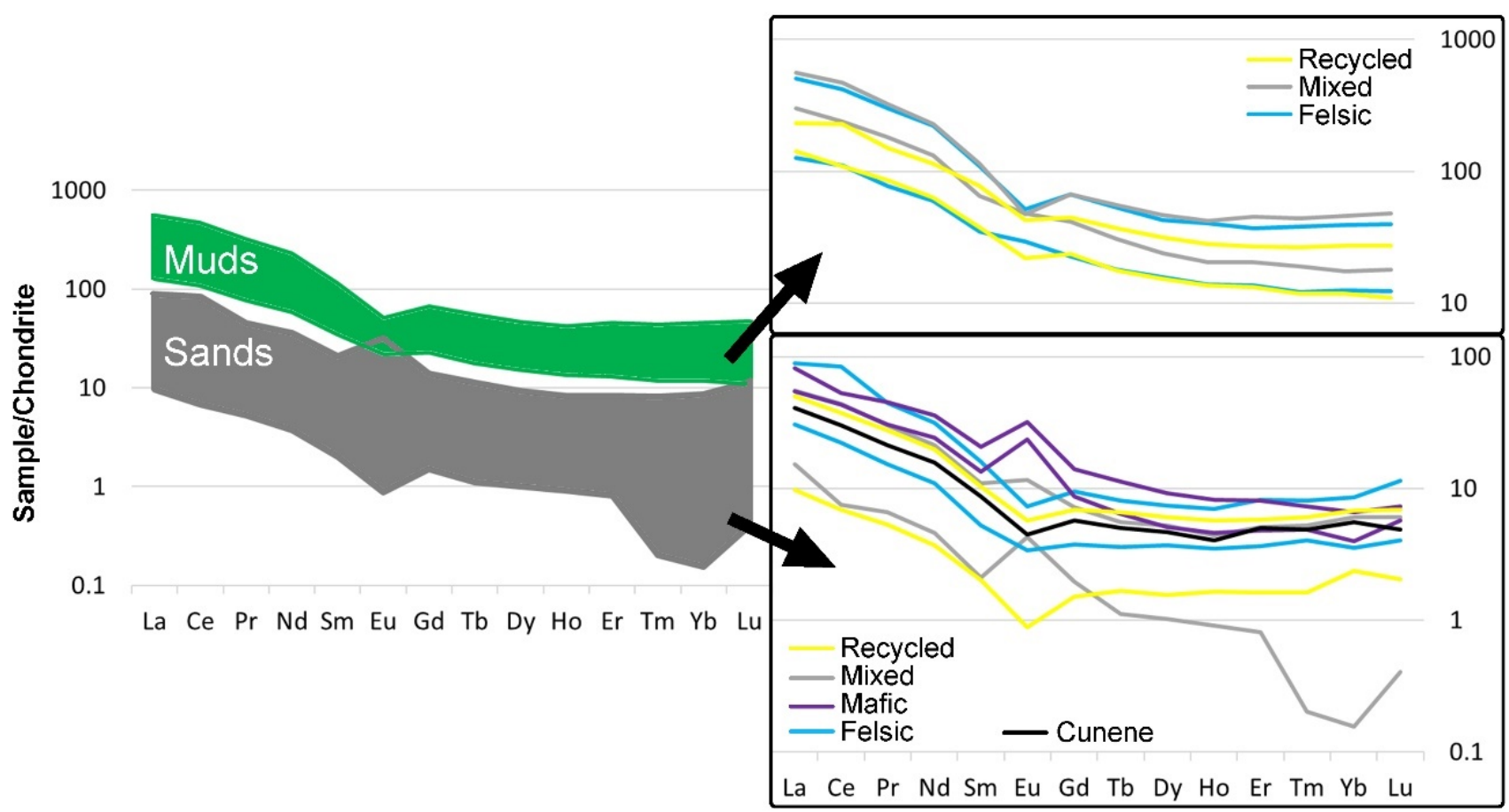

Figure 4. Overall REE composition of muds and sands, and patterns (maximum and minimum concentrations) for sands and muds with distinct source geologies. 

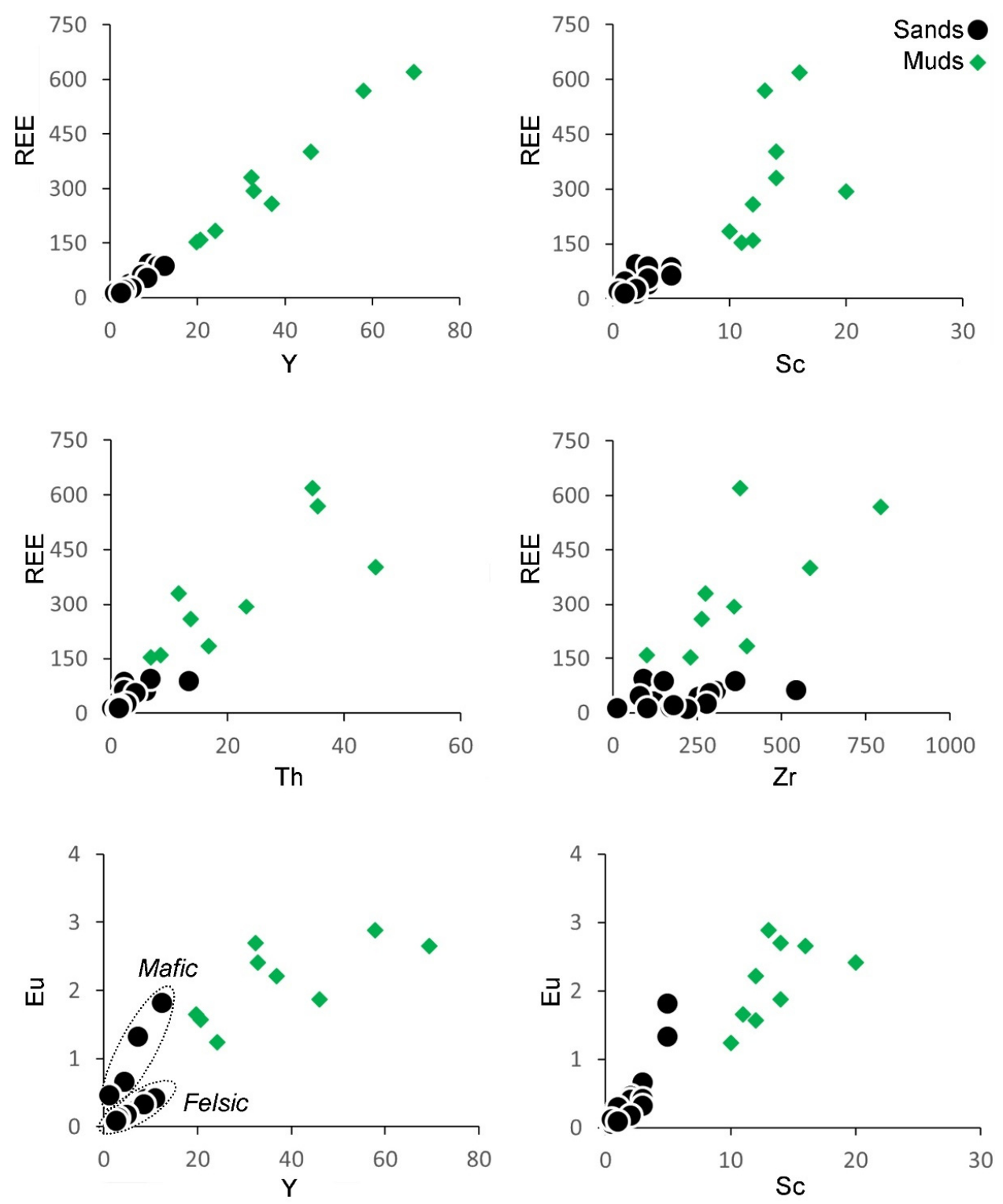

Figure 5. Relation between REE (lanthanides) and $\mathrm{Y}, \mathrm{Th}, \mathrm{Zr}$, and Sc.

The REE patterns are more homogenous in muds than in sands (Figures 4 and 6). Except for one sample with a mixed provenance that shows anomalously high $\mathrm{Gd}_{\mathrm{N}} / \mathrm{Yb}_{\mathrm{N}}(6.31$ in 37S), REE patterns for sands reveal substantially higher LREE fractionation $\left(3.41<\mathrm{La}_{\mathrm{N}} / \mathrm{Sm}_{\mathrm{N}}<7.25\right)$ than HREE fractionation $\left(0.58<\mathrm{Gd}_{\mathrm{N}} / \mathrm{Yb}_{\mathrm{N}}<2.19\right)$. The Eu anomaly is positive in mafic-derived sands $\left(1.85<\mathrm{Eu} / \mathrm{Eu}^{*}<2.11\right)$ and negative in both felsic-derived $\left(0.57<\mathrm{Eu} / \mathrm{Eu}^{*}<0.79\right)$ and recycled $\left(0.50<\mathrm{Eu} / \mathrm{Eu}^{*}<0.68\right)$ sands (Figure 5). Sands with a mixed mafic-felsic source yield widely variable Eu anomalies $\left(0.47<\mathrm{Eu} / \mathrm{Eu}^{*}<4.03\right)$. Samples with distinct source areas do not display substantially different $\mathrm{Ce}$ anomalies $\left(0.69<\mathrm{Ce} / \mathrm{Ce}^{*}<1.51\right)$, the extremes being measured in sands with a mixed provenance.

REE patterns for muds are characterized by slightly higher LREE fractionation $\left(2.39<\mathrm{La}_{\mathrm{N}} / \mathrm{Sm}_{\mathrm{N}}<5.49\right)$ than HREE fractionation $\left(1.33<\mathrm{Gd}_{\mathrm{N}} / \mathrm{Yb}_{\mathrm{N}}<2.37\right)$ (Figure 6). The Eu anomalies are negative in muds with felsic and recycled sources $\left(0.58<\mathrm{Eu} / \mathrm{Eu}^{*}<0.91\right)$, and slightly more variable in muds with mixed sources $\left(0.52<\mathrm{Eu} / \mathrm{Eu}^{*}<1.02\right)$. Except for one sample sourced exclusively from the sedimentary units of the Kalahari Basin (53L; $\left.\mathrm{Ce} / \mathrm{Ce}^{*}=1.35\right)$, muds display only minor, positive or negative, $\mathrm{Ce}$ anomalies $\left(0.87<\mathrm{Ce} / \mathrm{Ce}^{*}<1.15\right)$. 


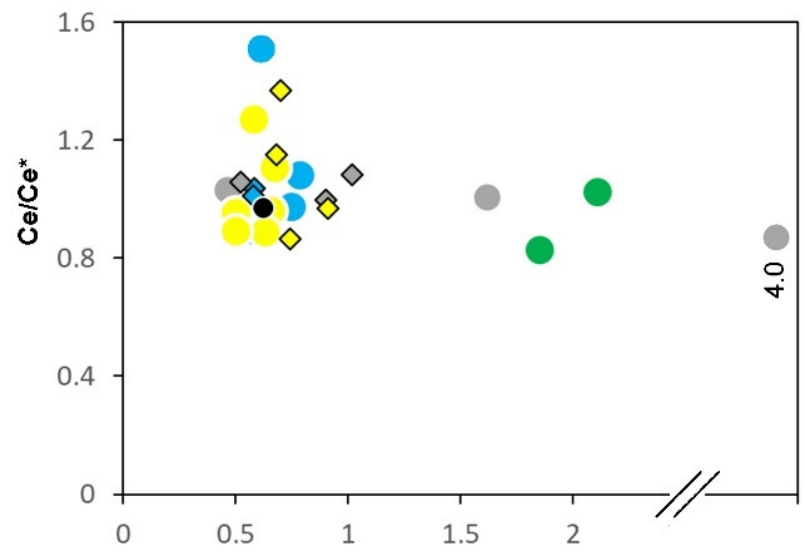

Cunene sand

Sand, mixed source

Sand, recycled source

Sands, mafic source

Sand, felsic source

$\diamond$ Mud, mixed source

$\diamond$ Mud, recycled source

$\diamond$ Mud, felsic source
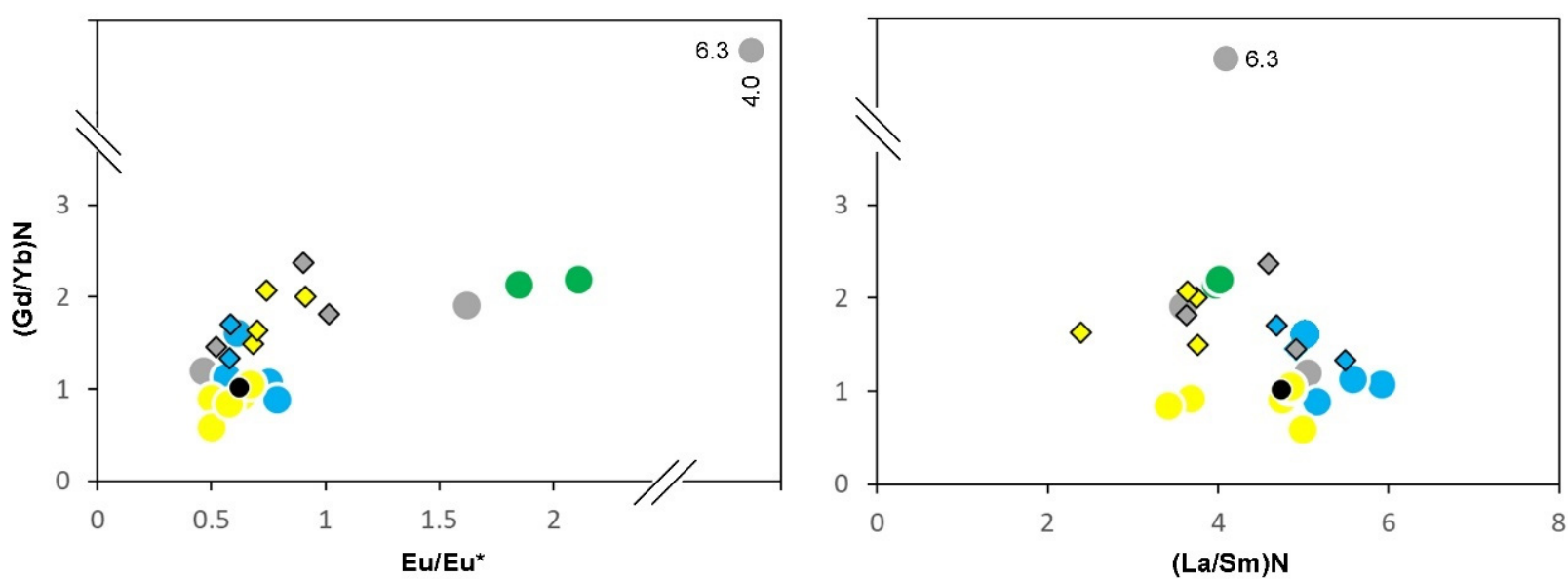

Figure 6. Biplots of characteristic fractionation and anomaly parameters for REE geochemistry.

\section{Discussion}

\subsection{Fingerprints of Primary Sources}

The total contents of REE in the studied samples with mafic and felsic sources are very similar. However, some features of the REE patterns, such as $\mathrm{Eu} / \mathrm{Eu}^{*}$ and the REE fractionation parameters $\mathrm{La}_{\mathrm{N}} / \mathrm{Yb}_{\mathrm{N}}$ and $\mathrm{Gd}_{\mathrm{N}} / \mathrm{Yb}_{\mathrm{N}}$, are higher in mafic- than felsic-derived deposits (Figure 6). The links between these parameters and primary source rocks become particularly evident in the PCA conducted with REE data and major chemical elements (Figure 7). In the PCA map, $\mathrm{Na}$ and $\mathrm{Ca}$ concentrations are plotted with $\mathrm{Eu} / \mathrm{Eu}^{*}$, reflecting the presence of Eu in plagioclase [4], which is abundant in mafic-derived deposits. These variables also appear linked with $\mathrm{La}_{\mathrm{N}} / \mathrm{Yb}_{\mathrm{N}}$ and $\mathrm{Gd}_{\mathrm{N}} / \mathrm{Yb}_{\mathrm{N}}$, demonstrating that $\mathrm{REE}$ parameters are good proxies of the mafic contribution. The studied mafic-derived sediments appear to display slightly steeper HREE patterns than sediments enriched in the felsic component. The biplot $\mathrm{Eu} / \mathrm{Y}$ also provides a good discrimination of sands with predominantly mafic and felsic sources, with higher Eu/Y in the former (Figure 5), confirming the ability of this ratio in the assessment of primary sources.

Sands with a mixed provenance can display REE patterns resembling either maficor felsic-dominated deposits (Figure 6). The dominant primary source can be estimated with the aforementioned REE parameters mentioned before $\left(\mathrm{Eu} / \mathrm{Y}, \mathrm{Eu} / \mathrm{Eu}^{*}, \mathrm{La}_{\mathrm{N}} / \mathrm{Yb}_{\mathrm{N}}\right.$, $\mathrm{La}_{\mathrm{N}} / \mathrm{Sm}_{\mathrm{N}}$, and $\mathrm{Gd}_{\mathrm{N}} / \mathrm{Yb}_{\mathrm{N}}$ ). At least concerning the REE contents, the contributions from different rock types do not directly mimic the spatial representation of these rock types in the drainage areas. In other words, some areas appear to be supplying more sediment than others. Note, for example, sample 37S, for which the REE patterns display a typical mafic fingerprint, but in its catchment, felsic rocks are even more abundant than mafic rocks (Table 1). In this case, the proximity to potential source rocks is crucial, as the sample was collected at the downstream end of the area with mafic outcrops, while felsic rocks 
are dominant only approximately $75 \mathrm{~km}$ upstream (Figure 2). A sample collected slightly upstream, closer to outcrops of felsic crystalline units and covering sedimentary successions (20aS), is much less enriched in the mafic component. The other sands, either with a mixed or recycled source, are dominated by the felsic component.

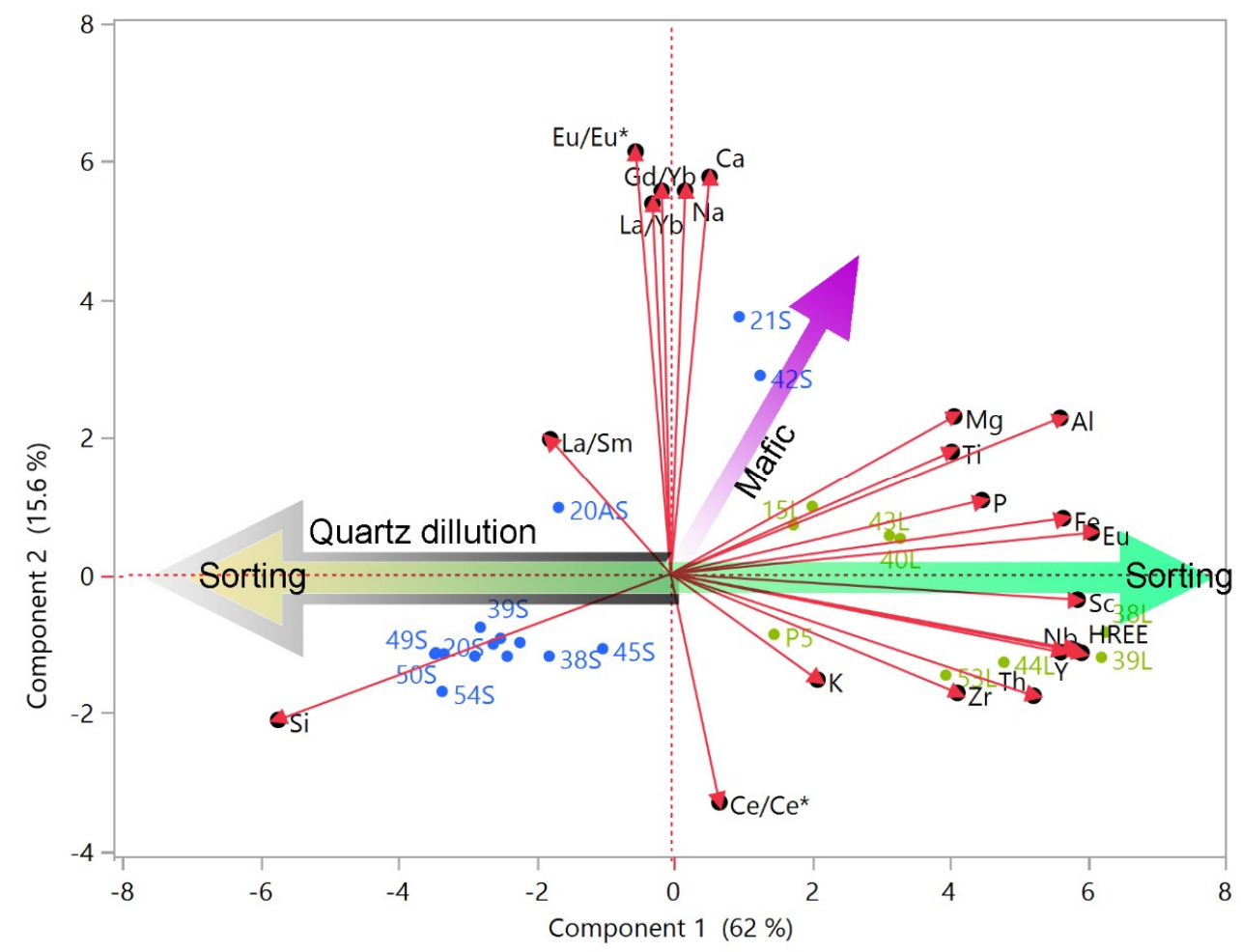

Figure 7. Map of the principal components obtained with a selection of major elements, REE concentrations, and parameters that characterize the REE patterns. See further explanation in the text.

The discrimination of source areas is not as obvious for muds. The highest mafic contributions appear to occur in 15L (Figure 7), but the composition is still not substantially different from some muds with a distinct provenance (e.g., 9L, 40L, 43L; Table 1). Although the geochemistry of fine-grained sediment fractions, frequently with an emphasis on REE, is an important tool in provenance investigations $[6,7,20,21,39,40]$, the present results show that the interference of other exogenous processes renders the recognition of source areas more complicated.

\subsection{Influence of Sediment Cycling on REE Geochemistry}

Comparisons of fluvial sediments with their source rocks indicated that depositional cycles are responsible for discernible changes in REE [14,41-45]. These transformations can be associated with a different process. In the following sections, we discuss the effects of weathering and sorting.

\subsubsection{Weathering}

REE are mobile within weathering profiles, particularly during the early stages of alteration [46,47]. Still, because of the decomposition of labile minerals that host minor REE and the retention of these elements in secondary minerals, weathering can promote an REE enrichment relative to the parent materials. To better understand the effect of weathering on REE, PCA was performed with parameters that characterize the REE geochemistry ( $L$ LREE, $\sum$ HREE, $\mathrm{Eu}, \mathrm{Eu} / \mathrm{Eu}^{*}, \mathrm{Ce} / \mathrm{Ce}^{*}, \mathrm{La}_{\mathrm{N}} / \mathrm{Yb}_{\mathrm{N}}, \mathrm{La}_{\mathrm{N}} / \mathrm{Sm}_{\mathrm{N}}$, and $\left.\mathrm{Gd}_{\mathrm{N}} / \mathrm{Yb}_{\mathrm{N}}\right)$ and a selection of compositional parameters that can be regarded as weathering proxies (Figure 8). 

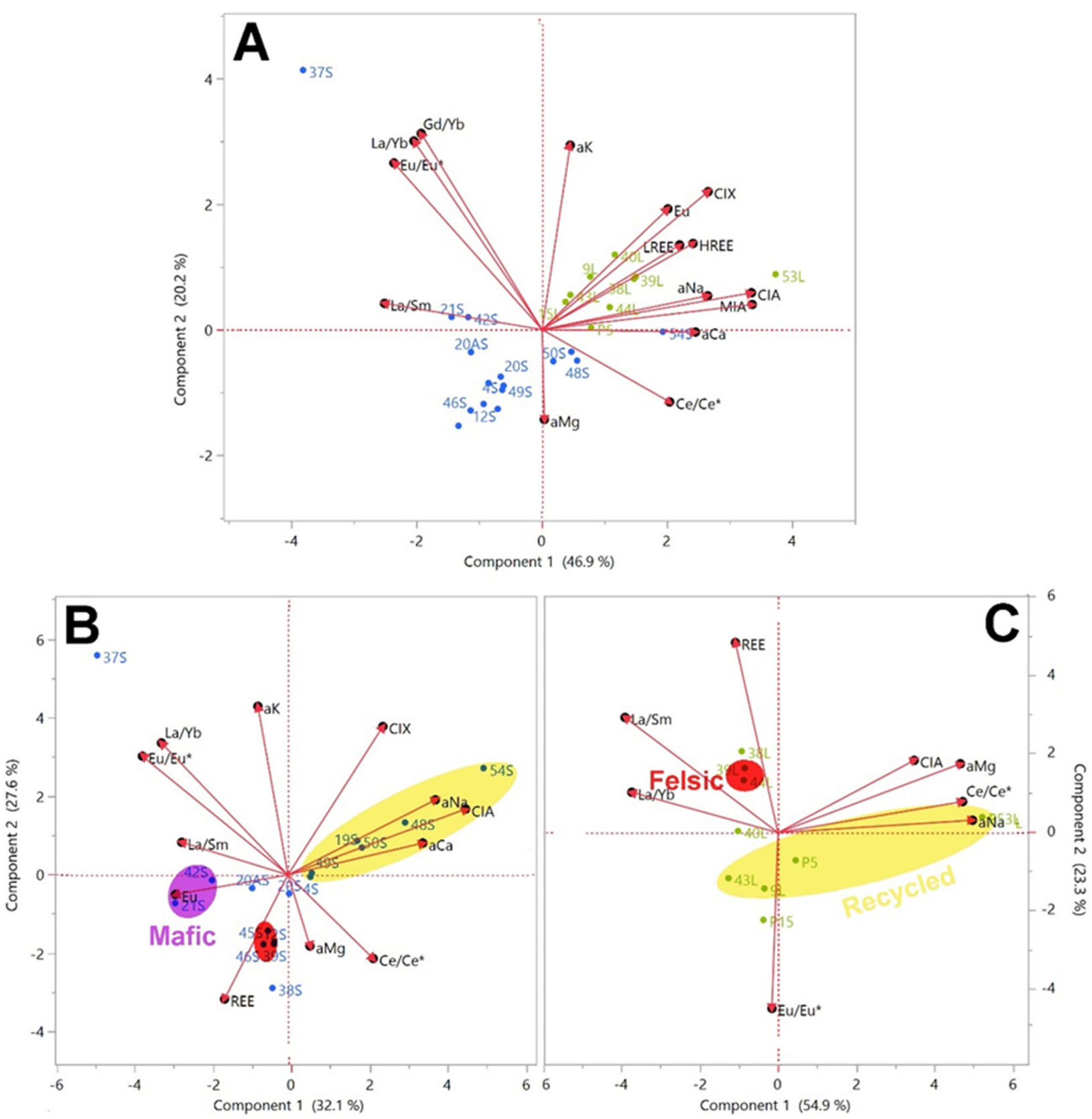

Figure 8. PCA map performed to assess the effect of weathering on REE geochemistry. Results for the entire dataset (A), sand deposits (B), and mud deposits (C) are presented. "a" stands for $\alpha$. See further explanation of weathering proxies and REE parameters in the text.

The extent of weathering transformations can be estimated through many different indices based on the concentration of major elements. Their formulations, advantages, and weaknesses were discussed in more detail elsewhere [48-50]. The parameters adopted in the PCA include the Chemical Index of Alteration (CIA; [51]), a modified CIA that does not consider $\mathrm{CaO}$ (CIX; [52]), and the Mafic Index of Alteration that also considers the fate of $\mathrm{Fe} / \mathrm{Mg}$ silicates (MIA; [53]). The values obtained for all these weathering proxies result from ratios between the concentrations of one or more non-mobile elements and the concentrations of sets of mobile elements in the sample (Table 3). In addition, the weathering intensity was assessed through the parameters $\alpha^{\mathrm{Al}} \mathrm{E}$ that measure the depletion of different mobile elements (E) using a ratio of their concentrations to the concentration of non-mobile element $\mathrm{Al}$ and applying a normalization to a reference material (e.g., UCC, as adopted in the present research) [54]. 
Table 3. Geochemical indices of weathering adopted in this research.

\begin{tabular}{cccc}
\hline Parameter & Formula (Where Necessary); Response to Weathering & Reference \\
\hline WIP (Weathering Index of Parker) & $\left(\mathrm{CaO}^{*} / 0.7+2 \mathrm{Na}_{2} \mathrm{O} / 0.35+2 \mathrm{~K}_{2} \mathrm{O} / 0.25+\mathrm{MgO} / 0.9\right) \times 100(1)$ & {$[55]$} \\
\hline CIA (Chemical Index of Alteration) & $\mathrm{Al}_{2} \mathrm{O}_{3} /\left(\mathrm{Al}_{2} \mathrm{O}_{3}+\mathrm{K}_{2} \mathrm{O}+\mathrm{CaO}^{*}+\mathrm{Na}_{2} \mathrm{O}\right) \times 100(1)$ & {$[51]$} \\
\hline$\alpha^{\mathrm{Al}}$ & $(\mathrm{Al} / \mathrm{E})_{\text {sample }} /(\mathrm{Al} / \mathrm{E})_{\mathrm{UCC}}$, with E a mobile element & {$[54]$} \\
\hline $\begin{array}{c}\mathrm{MIA}_{(\mathrm{o})}(\text { Mafic Index of Alteration, } \\
\text { oxidative conditions) }\end{array}$ & $\left(\mathrm{Al}_{2} \mathrm{O}_{3}+\mathrm{Fe}_{2} \mathrm{O}_{3}\right) \times 100 /\left(\mathrm{Al}_{2} \mathrm{O}_{3}+\mathrm{K}_{2} \mathrm{O}+\mathrm{CaO}^{*}+\mathrm{Na}_{2} \mathrm{O}+\mathrm{MgO}\right)(1)$ & {$[53]$} \\
\hline CIX (modified CIA) & $\mathrm{Al}_{2} \mathrm{O}_{3} /\left(\mathrm{Al}_{2} \mathrm{O} 3+\mathrm{K}_{2} \mathrm{O}+\mathrm{Na}_{2} \mathrm{O}\right) \times 100(1)$ & {$[52]$} \\
\hline
\end{tabular}

(1) Uses molar proportions. Cao*: silicate-bound $\mathrm{CaO}$. Except for WIP, all indices tend to increase with weathering.

Using both sand and mud samples, the PCA with weathering indices and REE features separates these two sets of deposits (Figure 8A). However, one sand sample collected in the upper reaches of the Caculuvar sub-basin that was sourced from meta-sedimentary units is plotted along with muds. This PCA also clusters most variables indicative of the weathering intensity (CIA, CIX, MIA, $\alpha^{\mathrm{Al}} \mathrm{Na}$, and $\alpha^{\mathrm{Al}} \mathrm{Ca}$ ) with LREE, HREE, and Eu in the region of the PCA where the mud deposits are plotted. Only $\alpha^{\mathrm{Al}} \mathrm{Mg}$ and $\alpha^{\mathrm{Al}} \mathrm{K}$, which are strongly influenced by the source rock composition $[18,56]$, are not grouped with the other weathering parameters, being plotted on opposite sides of the PCA map.

To remove the grain size effect on the sediment composition, two additional PCAs were performed for mud and sand deposits in separate. Due to the limited number of samples, some variables found to be redundant were not included $\left(\mathrm{Gd}_{\mathrm{N}} / \mathrm{Yb}_{\mathrm{N}}\right.$ and MIA in both PCAs; CIX, $\alpha^{\mathrm{Al}} \mathrm{K}$, and $\alpha^{\mathrm{Al}} \mathrm{Ca}$ in the PCA for muds) and only $\sum \mathrm{REE}$ was considered.

In the PCA map for sand deposits, $\mathrm{Eu} / \mathrm{Eu}^{*}$ and $\mathrm{La}_{\mathrm{N}} / \mathrm{Yb}_{\mathrm{N}}$ appear linked and in opposition to $\mathrm{Ce} / \mathrm{Ce}^{*}$, while weathering indices are plotted orthogonally, indicating that surface alteration is not a major factor influencing REE patterns (Figure 8B). Regarding muds, weathering indices appear to correlate with $\mathrm{Ce} / \mathrm{Ce}^{*}$ in opposition to fractionation indices (Figure $8 \mathrm{C}$ ), suggesting a concentration of Ce during surface alteration and a preferential release of La relative to Sm and HREE. The limited number of mud samples does not allow safe conclusions about weathering effects. However, they are compatible with the reported preferential mobilization of LREE $[14,57]$ and the concentration of Ce in secondary oxides formed during weathering [58,59]. The PCA for muds also shows REE contents in opposition to $\mathrm{Eu} / \mathrm{Eu}^{*}$. As secondary REE-bearing minerals tend to show stronger negative $\mathrm{Eu}$ anomalies (lower $\mathrm{Eu} / \mathrm{Eu}^{*}$ ) than the primary minerals they result from (e.g., feldspar, mica, and ferromagnesian silicates $[60,61])$, surface decomposition could be promoting REE enrichment.

\subsubsection{Sorting}

The segregation of sediment materials with different sizes, shapes, and densities plays a fundamental role in sediment geochemistry $[14,17,42,62,63]$. Significant amounts of REE in river sediments are hosted by particles whose concentrations are strongly influenced by sorting processes, such as heavy minerals [64-66] and clay minerals $[65,67,68]$. For the studied deposits, the PCA performed with geochemical data suggests that sorting is the principal factor determining the compositional variability (Figure 7).

Sorting accounts for the separation of fine-grained particles (clay to fine sand, depending on flow conditions) that are preferentially transported as suspended loads from coarser particles mainly transported as a bedload [69]. Muds are characterized by enrichment in elements that tend to be hosted in phyllosilicates, such as $\mathrm{Al}$ (clay minerals and micas), $\mathrm{Fe}$ and $\mathrm{Mg}$ (e.g., biotite, chlorite, and some illite), and K (muscovite and some illite). Titanium, along with very fine-grained REE minerals also tends to be concentrated with the finer fractions. On the other hand, sands are enriched in quartz and contain variable amounts of feldspars and minor heavy minerals. REE can also be frequently adsorbed onto clay minerals and Fe-Mn oxides, which may hold the majority of the leachable REE compo- 
nent [14]. Except for some mafic-derived sands, these deposits contain minor amounts of heavy mineral grains. Hence, sorting and quartz dilution are partially responsible for the low contents of most REE minerals in sands. Occasional exceptions are Eu, hosted in feldspars, and Ce, probably associated with coatings (Figure 9).
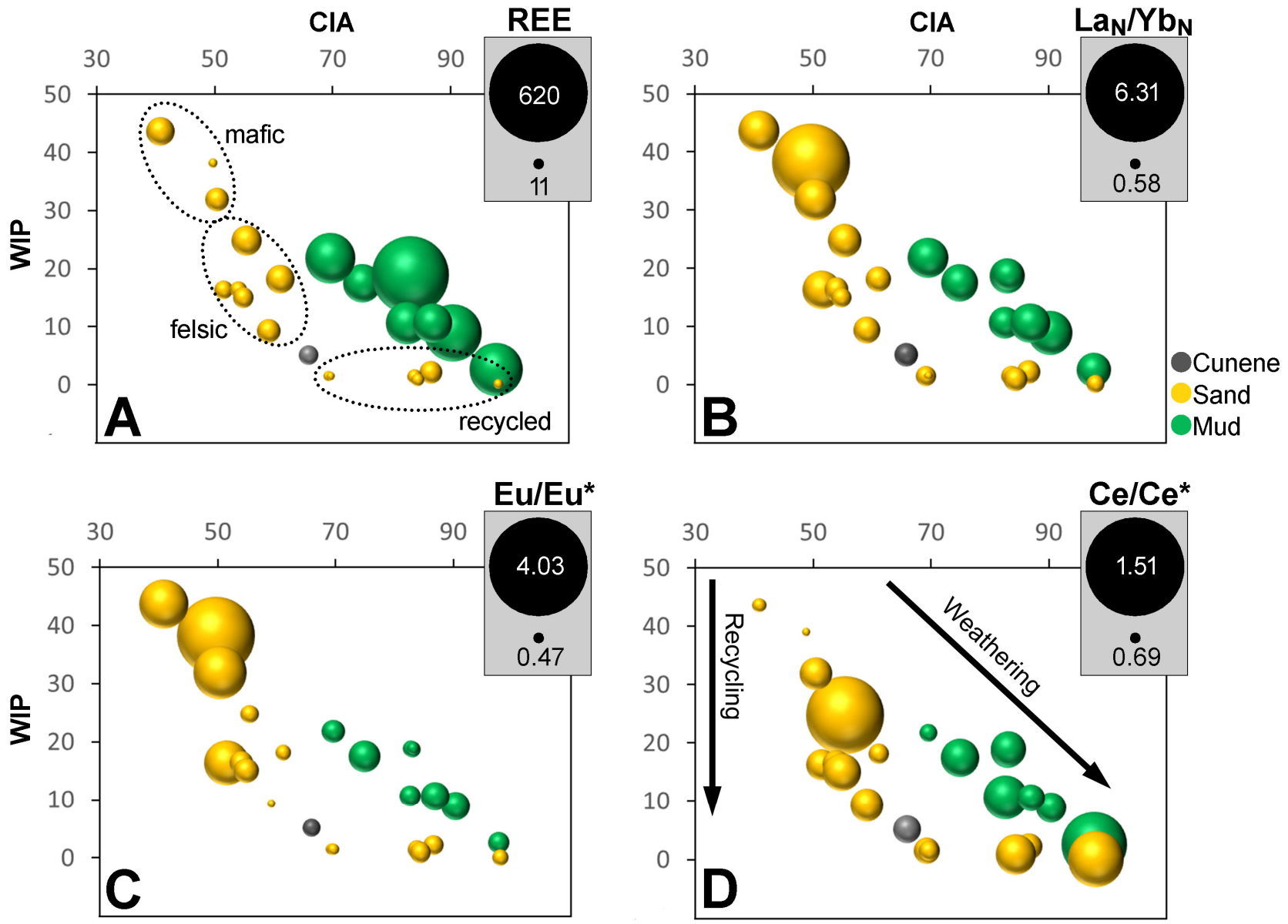

Figure 9. Plots of CIA-WIP applied to assess weathering, recycling, and grain size control on REE geochemistry. Bubble sizes represent $\sum \operatorname{REE}(\mathbf{A})$, REE fractionation determined as $\mathrm{La}_{\mathrm{N}} / \mathrm{Gd}_{\mathrm{N}}(\mathbf{B}), \mathrm{Eu}$ anomaly $(\mathbf{C})$, and Ce anomaly (D). Eu/Eu* is $\mathrm{Eu}$ anomaly; $\mathrm{Ce} / \mathrm{Ce}^{*}$ is $\mathrm{Ce}$ anomaly.

\subsubsection{Effect of Multiple Depositional Cycles}

Intense quartz dilution can be accomplished through recycling, which promotes a progressive enrichment in chemically stable and mechanically resistant minerals [70]. Feldspar is frequently the most abundant mineral of crystalline rocks that does not endure a sediment cycle as quartz. With the decrease in the feldspar contents, the negative Eu anomaly becomes progressively more evident, reflecting the release of Eu. Recycling is also responsible for the depletion of fine-grained detritus, which is frequently dominated by secondary clay minerals [50]. The quartz dilution effects on REE concentrations are particularly obvious for sands sourced from the Kalahari Group (Figure 7). These sediments are strongly enriched in quartz (92-100\%) and yield the lowest REE contents, with their geochemistry indicating that they are associated with the most intense surface decomposition (Figure 8). Different REE are not affected in the same way during sediment cycling. For example, LREE appears to be preferentially leached relative to HREE, leading to a decrease in $\mathrm{La}_{\mathrm{N}} / \mathrm{Yb}_{\mathrm{N}}$, but the higher values of $\mathrm{Ce} / \mathrm{Ce}^{*}$ show that $\mathrm{Ce}$ is not hosted by the same minerals as the remaining LREE. Part of it is likely retained in coatings that evolved sand grains instead of fine-grained particles, which tend to be preferentially lost during sediment cycles. 
Recycling effects can be assessed with a combination of compositional parameters. Unlike CIA and other indices used in this paper to assess the weathering intensity, the Weathering Index of Parker (WIP; [55]) is strongly influenced by the addition of recycled quartz. Hence, plots of CIA-WIP have been used to understand how recycling controls sediment composition [52,71]. Here, we used this biplot with a third dimension, the bubble size, to represent a feature of the REE geochemistry (Figure 9). The diagram clearly shows how quartz dilution in recycled sands is responsible for REE impoverishment. This set of samples is also characterized by particularly low $\mathrm{Eu} / \mathrm{Eu}^{*}$, responding to feldspar decomposition and breakdown, and flatter REE profiles due to the solubility of LREE. As expected, the composition of muds is not as affected by quartz dilution as observed with sands.

\section{Conclusions}

Sediment cycles, through weathering and sorting, influence the REE geochemistry of sands and muds differently. The decomposition of labile components and the segregation of particles according to size, shape, and density culminate with significant quartz enrichment in sand deposits, while mud deposits become enriched in secondary minerals. Quartz dilution explains the low REE content in sands, particularly in those most affected by recycling. Sand deposits with evidence of the most intense surface decomposition hold the lowest amounts of REE. As weathering transformations are accumulated during successive sediment cycles, the composition of recycled sands also points to more intense weathering, but the REE depletion should be ascribed to quartz dilution. REE concentrations in muds are influenced by two processes with opposite effects. Quartz dilution can be responsible for some REE depletion, while the decomposition of labile components and the retention of REE in secondary minerals account for some REE enrichment. The present research confirms that several parameters of REE geochemistry (e.g., $\mathrm{Eu} / \mathrm{Y}, \mathrm{Eu} / \mathrm{Eu}^{*}, \mathrm{La}_{\mathrm{N}} / \mathrm{Yb}_{\mathrm{N}}$, $\mathrm{La}_{\mathrm{N}} / \mathrm{Sm}_{\mathrm{N}}$, and $\left.\mathrm{Gd}_{\mathrm{N}} / \mathrm{Yb}_{\mathrm{N}}\right)$, particularly for sands, provide excellent information about the source geology. Surface decomposition seems to be responsible for an increase in Ce and some LREE depletion relative to HREE in muds but has no obvious consistent effects on the REE patterns of sands.

Supplementary Materials: The following are available online at https:/ /www.mdpi.com/article/10 .3390/geosciences11090384/s1.

Author Contributions: Conceptualization, P.A.D.; methodology, P.A.D. and A.G.; software, A.G., P.A.D. and P.L.; validation, A.C., P.A.D., A.G. and P.L.; formal analysis, A.C., P.A.D., A.G. and P.L.; investigation, A.C., P.A.D., A.G. and P.L.; resources, A.C., P.A.D. and A.G.; data curation, P.A.D. and A.G.; writing - original draft preparation, A.C., P.A.D., A.G. and P.L.; visualization, P.A.D., A.G. and P.L.; supervision, P.A.D. and A.G.; project administration, P.A.D. All authors have read and agreed to the published version of the manuscript.

Funding: This research was supported by national funds through FCT—Foundation for Science and Technology, I.P., within the scope of the project UIDB/04292/2020 (MARE).

Data Availability Statement: Topographic and climatic data used in SIG analysis can be downloaded from https://dwtkns.com/srtm30m/ (accessed on 7 January 2021) and https://www.worldclim. org/data/worldclim21.html (accessed on 26 March 2021), respectively.

Acknowledgments: The academic editor and three anonymous reviewers are warmly acknowledged for their constructive assessments that helped to improve the manuscript.

Conflicts of Interest: The authors declare no conflict of interest. The funders had no role in the design of the study; in the collection, analyses, or interpretation of data; in the writing of the manuscript, or in the decision to publish the results. 


\section{References}

1. Balaram, V. Rare earth elements: A review of applications, occurrence, exploration, analysis, recycling, and environmental impact. Geosci. Front. 2019, 10, 1285-1303. [CrossRef]

2. Dushyantha, N.; Batapola, N.; Ilankoon, I.M.S.K.; Rohitha, S.; Premasiri, R.; Abeysinghe, B.; Dissanayake, K. The story of rare earth elements (REEs): Occurrences, global distribution, genesis, geology, mineralogy and global production. Ore Geol. Rev. 2020, 122, 103521. [CrossRef]

3. Zhou, B. Global potential of rare earth resources and rare earth demand from clean technologies. Minerals 2017, 7, 203. [CrossRef]

4. McLennan, S.M. Rare Earth Elements in Sedimentary Rocks: Influence of Provenance and Sedimentary Processes. In Geochemistry and Mineralogy of Rare Earth Elements; Lipinand, B.R., McKay, G.A., Eds.; Mineralogical Society of America: Chantilly, VA, USA, 1989; pp. 169-200.

5. Singh, P.; Rajamani, V. REE geochemistry of recent clastic sediments from the Kaveri floodplains, southern India: Implication to source area weathering and sedimentary processes. Geochim. Cosmochim. Acta. 2001, 65, 3093-3108. [CrossRef]

6. Munksgaard, N.C.; Lim, K.; Parry, D.L. Rare earth elements as provenance indicators in North Australian estuarine and coastal marine sediments. Estuar. Coast. Shelf Sci. 2003, 57, 399-409. [CrossRef]

7. Ferrat, M.; Weiss, D.J.; Strekopytov, S.; Dong, S.; Chen, H.; Najorka, J.; Sinha, R. Improved provenance tracing of Asian dust sources using rare earth elements and selected trace elements for palaeomonsoon studies on the eastern Tibetan Plateau. Geochim. Cosmochim. Acta 2011, 75, 6374-6399. [CrossRef]

8. Blake, J.M.; Peters, S.C.; Johannesson, K.H. Application of REE geochemical signatures for Mesozoic sediment provenance to the Gettysburg Basin, Pennsylvania. Sediment. Geol. 2017, 349, 103-111. [CrossRef]

9. Wang, L.; Han, X.; Ding, S.; Liang, T.; Zhang, Y.; Xiao, J.; Zhang, H. Combining multiple methods for provenance discrimination based on rare earth element geochemistry in lake sediment. Sci. Total Environ. 2019, 672, 264-274. [CrossRef]

10. Condie, K.C.; Dengate, J.; Cullers, R.L. Behavior of rare earth elements in a paleoweathering profile on granodiorite in the Front Range, Colorado, USA. Geochim. Cosmochim. Acta 1995, 59, 279-294. [CrossRef]

11. Morey, G.B.; Setterholm, D.R. Rare earth elements in weathering profiles and sediments of Minnesota; Implications for provenance studies. Sediment. Res. 1997, 67, 105-115.

12. Ahmad, M.Z.; Singh, P. Implication of weathering and mineral sorting on rare earth element geochemistry of Pleistocene-Holocene sediments from Cauvery delta, south India. Earth Syst. Sci. 2020, 129, 1-22. [CrossRef]

13. Aubert, D.; Stille, P.; Probst, A.A. REE fractionation during granite weathering and removal by waters and suspended loads: Sr and $\mathrm{Nd}$ isotopic evidence. Geochim. Cosmochim. Acta 2021, 65, 387-406. [CrossRef]

14. Su, N.; Yang, S.; Guo, Y.; Yue, W.; Wang, X.; Yin, P.; Huang, X. Revisit of rare earth element fractionation during chemical weathering and river sediment transport. Geochem. Geophys. Geosyst. 2017, 18, 935-955. [CrossRef]

15. Ma, J.L.; Wei, G.J.; Xu, Y.F.; Long, W.G.; Sun, W.D. Mobilization and re-distribution of major and trace elements during extreme weathering of basalt in Hainan Island, South China. Geochim. Cosmochim. Acta 2007, 71, 3223-3237. [CrossRef]

16. Yusoff, Z.M.; Ngwenya, B.T.; Parson, I. Mobility and fractionation of REEs during deep weathering of geochemically contrasting granites in a tropical setting, Malaysia. Chem. Geol. 2013, 349-350, 71-86. [CrossRef]

17. Wu, K.; Liu, S.; Kandasamy, S.; Jin, A.; Lou, Z.; Li, J.; Shi, X. Grain-size effect on rare earth elements in Pahang River and Kelantan River, Peninsular Malaysia: Implications for sediment provenance in the southern South China Sea. Conti. Shelf Res. 2019, 189, 103977. [CrossRef]

18. Dinis, P.; Garzanti, E.; Vermeesch, P.; Huvi, J. Climatic zonation and weathering control on sediment composition. Angola Chem. Geol. 2017, 467, 110-121. [CrossRef]

19. Guo, Y.; Yang, S.; Su, N.; Li, C.; Yin, P.; Wang, Z. Revisiting the effects of hydrodynamic sorting and sedimentary recycling on chemical weathering indices. Geoch. Cosmoch. Acta 2018, 227, 48-63. [CrossRef]

20. Xu, Z.; Lim, D.; Choi, J.; Yang, S.; Jung, H. Rare earth elements in bottom sediments of major rivers around the Yellow Sea: Implications for sediment provenance. Geo-Mar. Lett. 2009, 29, 291-300. [CrossRef]

21. Xu, F.; Hu, B.; Dou, Y.; Liu, X.; Wan, S.; Xu, Z.; Li, A. Sediment provenance and paleoenvironmental changes in the northwestern shelf mud area of the South China Sea since the mid-Holocene. Contin. Shelf Res. 2017, 144, 21-30. [CrossRef]

22. Araújo, A.G.; Guimarâes, F.; Perevalov, O.V.; Voinovsky, A.S.; Tselikovosky, A.F.; Agueev, Y.L.; Polskoi, F.R.; Khodirev, V.L.; Kondrátiev, A.I. Geologia de Angola-Notícia Explicativa da Carta Geológica de Angola à escala de 1:1,000,000. Serv. Geológ. Ang. 1992. Available online: https:// www.worldcat.org/title/geologia-de-angola-noticia-explicativa-da-carta-geologica-a-escala11000000 /oclc/71310190 (accessed on 26 March 2021). (In Portuguese)

23. Correia, H. O Grupo da Chela e Formação da Leba como novas unidades litoestratigráficas resultantes da redefinição da Formação da Chela na região do Planalto da Humpata. Sudoeste de Angola. Bol. Soc. Geol. Port. 1976, 20, 65-130.

24. Pereira, E.; Tassinari, C.C.; Rodrigues, J.F.; Van-Dúnem, M.V. New data on the deposition age of the volcano-sedimentary Chela Group and its Eburnean basement: Implications to post-Eburnean crustal evolution of the SW of Angola. Comun.Geol. 2011, 98, $29-40$.

25. Ernest, R.E.; Pereira, E.; Hamilton, M.A.; Pisarevsky, S.A.; Rodriques, J.; Tassinari, C.C.; Van-Dunem, V. Mesoproterozoic intraplate magmatic 'barcode' record of the Angola portion of the Congo Craton: Newly dated magmatic events at 1505 and 1110 Ma and implications for Nuna (Columbia) supercontinent reconstructions. Precamb. Res. 2013, 230, 103-118. [CrossRef]

26. Carvalho, H. Estratigrafia do Precâmbrico de Angola. Garcia Orta 1984, 7, 1-66. 
27. Carvalho, H.; Tassinari, C.; Alves, P.; Guimarães, F.; Simões, M. Geochronological review of the Precambrian in Western Angola: Links with Brazil. Afr. Earth Sc. 2000, 31, 383-402. [CrossRef]

28. Morais, E.; Sinigoi, S.; Mayer, A.; Mucana, A.; Rufino Neto, J. The Kunene gabbroanorthosite complex: Preliminary results based on the new field and chemical data. Afr. Geosc. Rev. 1998, 5, 485-498.

29. Mayer, A.; Hofmann, A.W.; Sinigoi, S.; Morais, E. Mesoproterozoic Sm-Nd and U-Pb ages for the Kunene anorthosite complex of SW Angola. Precamb. Res. 2004, 133, 187-206. [CrossRef]

30. Drüppel, K.; Littmann, S.; Romer, R.L.; Okrusch, M. Petrology and isotopic geochemistry of the Mesoproterozoic anorthosite and related rocks of the Kunene Intrusive Complex, NW Namibia. Precamb. Res. 2007, 156, 1-31. [CrossRef]

31. Haddon, I.G.; McCarthy, T.S. The mesozoic-cenozoic interior sag basins of central Africa: The late-cretaceous-cenozoic Kalahari and okavango basins. J. Afr. Earth Sci. 2005, 43, 316-333. [CrossRef]

32. Huntley, B.J. Angola in Outline: Physiography, Climate and Patterns of Biodiversity. In Biodiversity of Angola; Huntley, B., Russo, V., Lages, F., Ferrand, N., Eds.; Springer: Cham, Switzerland, 2019; pp. 15-42.

33. Dieppois, B.; Rouault, M.; New, M. The impact of ENSO on Southern African rainfall in CMIP5 ocean atmosphere coupled climate models. Clim. Dynam. 2015, 45, 2425-2442. [CrossRef]

34. Crétat, J.; Pohl, B.; Dieppois, B.; Berthou, S.; Pergaud, J. The Angola Low: Relationship with southern African rainfall and ENSO. Clim. Dynam. 2019, 52, 1783-1803. [CrossRef]

35. Cook, C.; Reason, J.C.; Hewitson, B.C. Wet and dry spells within particularly wet and dry summers in the South African summer rainfall region. Clim. Res. 2004, 26, 17-31. [CrossRef]

36. Rudnick, R.L.; Gao, S. Composition of the Continental Crust. In Treatise on Geochemistry: The Crust; Rudnick, R.L., Holland, H.D., Turekian, K.K., Eds.; Elsevier: Oxford, UK, 2003; pp. 1-64.

37. Hu, Z.; Gao, S. Upper crustal abundances of trace elements: A revision and update. Chem. Geol. 2008, 253, 205-221. [CrossRef]

38. McDonough, W.F.; Sun, S.S. The composition of the Earth. Chem. Geol. 1995, 120, 223-253. [CrossRef]

39. Roser, B.P.; Korsch, R.J. Provenance signatures of sandstone-mudstone suites determined using discriminant function analysis of major-element data. Chem. Geol. 1988, 67, 119-139. [CrossRef]

40. McLennan, S.M.; Hemming, S.; McDaniel, D.K.; Hanson, G.N. Geochemical approaches to sedimentation, provenance, and tectonics. Spec.Papers-Geol. Soc. Am. 1993, 21. [CrossRef]

41. Dinis, P.A.; Oliveira, Á.; Rocha, F.; Vieira, M.; Cunha, P.P. Evolution in the provenance of a tectonically controlled Plio-Pleistocene alluvial system between the Variscan Iberian Massif and the Atlantic margin. Portugal. Chem. Erde-Geochem. 2011, 71, 267-278. [CrossRef]

42. Bayon, G.; Toucanne, S.; Skonieczny, C.; André, L.; Bermell, S.; Cheron, S.; Barrat, J.A. Rare earth elements and neodymium isotopes in world river sediments revisited. Geochim. Cosmochim. Acta 2015, 170, 17-38. [CrossRef]

43. Perri, F.; Caracciolo, L.; Cavalcante, F.; Corrado, S.; Critelli, S.; Muto, F.; Dominici, R. Sedimentary and thermal evolution of the Eocene-Oligocene mudrocks from the southwestern Thrace Basin (NE Greece). Basin Res. 2016, 28, 319-339. [CrossRef]

44. Dinis, P.; Oliveira, Á. Provenance of Pliocene clay deposits from the Iberian Atlantic Margin and compositional changes during recycling. Sediment. Geol. 2016, 336, 171-182. [CrossRef]

45. Kumar, M.; Goswami, R.; Awasthi, N.; Das, R. Provenance and fate of trace and rare earth elements in the sediment-aquifers systems of Majuli River Island, India. Chemosphere 2019, 237, 124477. [CrossRef]

46. Nesbitt, H.W. Mobility and fractionation of rare earth elements during weathering of a granodiorite. Nature 1979, 279, 206-210. [CrossRef]

47. Duddy, L.R. Redistribution and fractionation of rare-earth and other elements in a weathering profile. Chem. Geol. 1980, 30, 363-381. [CrossRef]

48. Duzgoren-Aydin, N.S.; Aydin, A.; Malpas, J. Re-assessment of chemical weathering indices: Case study on pyroclastic rocks of Hong Kong. Eng. Geol. 2002, 63, 99-119. [CrossRef]

49. Price, J.R.; Velbel, M.A. Chemical weathering indices applied to weathering profiles developed on heterogeneous felsic metamorphic parent rocks. Chem. Geol. 2003, 202, 397-416. [CrossRef]

50. Dinis, P.A.; Garzanti, E.; Hahn, A.; Vermeesch, P.; Pinto, M.C. Weathering indices as climate proxies. A step forward based on Congo and SW African river muds. Earth Sci. Rev. 2020, 201, 103039. [CrossRef]

51. Nesbitt, H.W.; Young, G.M. Early Proterozoic climates and plate motions inferred from major element chemistry of lutites. Nature 1982, 299, 715-717. [CrossRef]

52. Garzanti, E.; Padoan, M.; Setti, M.; L'opez-Galindo, A.; Villa, I.M. Provenance versus weathering control on the composition of tropical river mud (Southern Africa). Chem. Geol. 2014, 366, 61-74. [CrossRef]

53. Babechuk, M.G.; Widdowson, M.; Kamber, B.S. Quantifying chemical weathering intensity and trace element release from two contrasting basalt profiles, Deccan Traps, India. Chem. Geol. 2014, 363, 56-75. [CrossRef]

54. Garzanti, E.; Padoan, M.; Setti, M.; Peruta, L.; Najman, Y.; Villa, I.M. Weathering geochemistry and Sr-Nd isotope fingerprints of equatorial upper Nile and Congo muds. Geochem. Geophys. Geosyst. 2013, 14, 292-316. [CrossRef]

55. Parker, A. An index of weathering for silicate rocks. Geol. Mag. 1970, 107, 501-504. [CrossRef]

56. Garzanti, E.; Resentini, A. Provenance control on chemical indices of weathering (Taiwan river sands). Sediment. Geol. 2016, 336, 81-95. [CrossRef] 
57. Laveuf, C.; Cornu, S. A review on the potentiality of rare earth elements to trace pedogenetic processes. Geoderma 2009, 154, 1-12. [CrossRef]

58. Davranche, M.; Pourret, O.; Gruau, G.; Dia, A.; Jin, D.; Gaertner, D. Competitive binding of REE to humic acid and manganese oxide: Impact of reaction kinetics on development of cerium anomaly and REE adsorption. Chem. Geol. 2008, 247, 154-170. [CrossRef]

59. Li, M.Y.H.; Zhou, M.F.; Williams-Jones, A.E. Controls on the dynamics of Rare Earth Elements during subtropical hillslope processes and formation of regolith-hosted deposits. Econ. Geol. 2020, 115, 1097-1118. [CrossRef]

60. Gao, S.; Wedepohl, K.H. The negative Eu anomaly in Archean sedimentary rocks: Implications for decomposition age and importance of their granitic sources. Earth Planet. Sci. Lett. 1995, 133, 81-94. [CrossRef]

61. González-Álvarez, I.; Kerrich, R. Weathering intensity in the Mesoproterozoic and modern large-river systems: A comparative study in the Belt-Purcell Supergroup. Canada and USA. Precamb. Res. 2012, 208-211, 174-196. [CrossRef]

62. Garzanti, E.; Andò, S.; France-Lanord, C.; Vezzoli, G.; Censi, P.; Galy, V.; Najman, Y. Mineralogical and chemical variability of fluvial sediments: 1. Bedload sand (Ganga-Brahmaputra, Bangladesh). Earth Planet. Sci. Lett. 2010, 299, 368-381. [CrossRef]

63. Garzanti, E.; Andó, S.; France-Lanord, C.; Censi, P.; Vignola, P.; Galy, V.; Lupker, M. Mineralogical and chemical variability of fluvial sediments 2. Suspended-load silt (Ganga-Brahmaputra, Bangladesh). Earth Planet. Sci. Lett. 2011, 302, 107-120. [CrossRef]

64. Vital, H.; Stattegger, K. Major and trace elements of stream sediments from the lowermost Amazon River. Chem. Geol. 2000, 168, 151-168. [CrossRef]

65. Yang, S.Y.; Jung, H.S.; Choi, M.S.; Li, C.X. The rare earth element compositions of the Changjiang (Yangtze) and Huanghe (Yellow) river sediments. Earth Planet. Sci. Lett. 2002, 201, 407-419. [CrossRef]

66. He, M.; Zheng, H.; Clift, P.D.; Tada, R.; Wu, W.; Luo, C. Geochemistry of fine-grained sediments in the Yangtze River and the implications for provenance and chemical weathering in East Asia. Prog. Earth Planet. Sci. 2015, 2, 1-20. [CrossRef]

67. Cullers, R.L.; Chaudhuri, S.; Arnold, B.; Lee, M.; Wolf, C.W., Jr. Rare earth distributions in clay minerals and the clay-sized fraction of the Lower Permian Havensville and Eskridge shales of Kansas and Oklahoma. Geochim. Cosmochim. Acta 1975, 39, 1691-1703. [CrossRef]

68. Condie, K.C. Another look at rare earth elements in shales. Geochim. Cosmochim. Acta 1991, 55, 2527-2531. [CrossRef]

69. Turowski, J.M.; Rickenmann, D.; Dadson, S.J. The partitioning of the total sediment load of a river into suspended load and bedload: A review of empirical data. Sedimentology 2019, 57, 1126-1146. [CrossRef]

70. Garzanti, E.; Vermeesch, P.; Vezzoli, G.; Andò, S.; Botti, E.; Limonta, M.; Dinis, P.; Hahn, A.; Baudet, D.; De Grave, J.; et al. Congo River sand and the equatorial quartz factory. Earth Sci. Rev. 2019, 197, 102918. [CrossRef]

71. He, J.; Garzanti, E.; Dinis, P.; Yang, S.; Wang, H. Provenance versus weathering control on sediment composition in tropical monsoonal climate (South China)-1. Geochemistry and clay mineralogy. Chem. Geol. 2020, 558, 119860. [CrossRef] 